\title{
ISLAM DAN PEMBASMIAN KEMISKINAN BANDAR
}

\section{Islam and the Erradication of Urban Poverty}

\author{
Muhamad Zulfadli Abdul Rahman ${ }^{1}$ \\ Mohammad Taqiuddin Mohamad ${ }^{2}$ \\ Muhammad Shamshinor Abdul Azzis ${ }^{3}$
}

\begin{abstract}
Urbanisation has created a disparity between the standard of living in urban and rural areas. Subsequently, more and more people are migrating from the rural areas to the urban areas due to the lure of wider economic opportunities and greater access to infrastructure and facilities. Unfortunately, massive urban migration gradually limited economic opportunities for migrants, and this has led to wide-spread urban poverty. This article will explain the phenomenon of urban poverty and discuss urban poverty eradication from an Islamic perspective. This study employs the qualitative approach by applying the inductive, deductive and comparative content analysis method where the primary data are derived from library research, as well as from previous studies. The study found that the authority and community both play an important role in addressing urban poverty. This can be addressed through several measures of poverty eradication
\end{abstract}

$1 \mathrm{PhD}$ Candidate, Department of Shariah and Economy, Academy of Islamic Studies, University of Malaya, zulfadlirahman90@gmail.com

2 Senior Lecturer, Department of Shariah and Economy, Academy of Islamic Studies, University of Malaya, m.taqiuddin@um.edu.my

3 Lecturer, Centre for Intership Training and Academic Enrichment (CITrA) Universiti of Malaya, shamshinor@um.edu.my 
implemented in Islam, which include correcting belief about the economy, ensuring a balance wealth distribution from the rich to the poor, and changing attitudes and motivation at the ground level. In this regard, the authority should focus on creating a balanced distribution of wealth, facilitating a strategic economic management plan, adopting priority-based economies, effective implementation of poverty eradication policies, adoption of growth strategies, improving basic facilities and focusing on institutional roles.

Keywords: poverty, urban poverty, Islam

\section{PENGENALAN}

Kajian kemiskinan ini adalah satu kajian yang popular dan tiada pernah ada penghujungnya. Malah, kajian berkaitan kemiskinan sentiasa menjadi tumpuan pengkaji-pengkaji daripada latarbelakang bidang yang pelbagai. Isu kemiskinan sentiasa mendapat perhatian oleh semua pihak supaya kemakmuran ekonomi akan dinikmati oleh seluruh masyarakat. Isu kemiskinan senantiasa berkembang dan berubah, meskipun telah banyak usaha dan strategi dilaksanakan oleh pelbagai pihak menunjukkan kejayaan. Kemiskinan bandar telah menyebabkan kewujudan kumpulan masyarakat berdasarkan kepada beberapa jenis kumpulan mengikut tahap pendapatan yang dimiliki oleh setiap isi rumah. Pengkelasan ini dapat dibahagikan kepada empat jenis kumpulan utama, iaitu: 1) Tertinggi 20\% atau Top 20\% (T20); 2) Pertengahan $40 \%$ atau Medium 40\% (M40); 3) Bawah 40\% atau Below 40\% (B40) dan; 4) Bawah $20 \%$ atau Below $20 \%$ (B20). ${ }^{4}$

Walau bagaimanapun, laporan daripada Uni Perancang Ekonomi melaporkan bahawa sehingga tahun 2016, golongan masyarakat B40 merupakan golongan penduduk yang tertinggi iaitu sebanyak $60 \%$ terutamanya di kawasan bandar. $^{5}$ Penelitian yang telah dijalankan terhadap kumpulan pendapatan miskin bandar ini dapat dijelaskan kebanyakan mereka yang berada dalam kumpulan B40 dan kebawah mempunyai anggaran pendapatan dibawah RM3,000.00 sebulan. ${ }^{6}$ Hasil dapatan ini dperkukuhkan lagi oleh dapatan Jayasooria (2016) yang

4 Economic Planning Unit, The Malaysian Economy in Figure 2016 (Putrajaya: Economic Planning Unit, 2016), 4.

5 Economic Planning Unit, The Malaysian Economy in Figure 2016, 4.

6 Jabatan Perangkaan Malaysia, Laporan Penyiasatan Pendapatan Isi Rumah dan Kemudahan Asas Mengikut Negeri dan Daerah Pentadbiran (Kuala Lumpur: Jabatan Perangkaan Malaysia, 2017), 5. 
menunjukkan sebanyak $56 \%$ penduduk di bandar memperoleh pendapatan di bawah RM 2,537.00 sebulan. ${ }^{7}$ Ini menunjukkan, istilah kemiskinan bandar mula diperkenalkan di Malaysia yang merujuk kepada mereka yang mempunyai pendapatan sebanyak RM3,000.00 sebulan dan ke bawah. Justeru, penduduk bandar yang berada dalam golongan B40 dan ke bawah boleh diklasifikasikan sebagai miskin bandar di Malaysia. Perkembangan ini memerlukan kepekaan semua pihak khususnya pembuat dasar dan pengkaji untuk sentiasa proaktif dan responsif melakukan penambahbaikan serta inovasi terhadap perubahan dimensi kajian yang berlaku sebagai langkah mengatasi masalah rakyat yang tergolong di bawah daripada $40 \%$ pendapatan negara. ${ }^{8}$

Kembali kepada konsep asas kemiskinan, menurut Ravallion, kemiskinan bermaksud individu yang tidak mempunyai cukup pendapatan dalam memenuhi kesejahteraan ekonominya ataupun dalam istilah ekonomi dikatakan mengalami kekurangan kebajikan ekonomi. ${ }^{9}$ Kemiskinan berlaku apabila sebahagian daripada masyarakat tidak berpeluang untuk menikmati kemewahan seperti yang dinikmati oleh sebahagian dari masyarakat umum di sekeliling mereka. Kemiskinan menandakan kegagalan sesebuah masyarakat melibatkan diri dalam sektor ekonomi pada tahap minimum hingga menjejaskan kemampuan mereka untuk menampung kehidupan dengan baik dan sempurna. ${ }^{10}$ Selain daripada kekurangan pendapatan, mereka juga tidak mempunyai keupayaan dan laluan kepada sumber kuasa sosial seperti politik, punca pengeluaran dan pendidikan. ${ }^{11}$

Kemiskinan dapat dibahagikan kepada dua jenis iaitu kemiskinan mutlak dan kemiskinan relatif. Kemiskinan mutlak merujuk kepada ketidakmampuan untuk mendapatkan keperluan asas minimum untuk meneruskan kehidupan

7 Denison Jayasooria, Inclusive Development for Urban Poor and Bottom 40\% Communities in Malaysia (Bangi: Institut Kajian Etnik Universiti Kebangsaan Malaysia, 2016), 36.

8 Unit Perancang Ekonomi, Rancangan Malaysia Kesepuluh (Putrajaya: Unit Perancang Ekonomi Jabatan Perdana Menteri 2010), 153.

9 Martin Ravallion, 'Poverty Lines in Theory and Practice', Living Standards Measurement Study Working Paper, no. 33 (1998), 6.

10 Gerald Rosenthal, 'Identifying the Poor: Economic Measures of Poverty,' in On Understanding Poverty, ed. Danial P. Moynihan Moynihan (New York: Basic Book Inc. Publisher, 1969), 334.

11 Kamal Salih, 'Konsep, Definisi dan Pengukuran Kemiskinan', dalam Kemiskinan Luar Bandar, ed. Aladin H., Alang Perang \& A.W. Hashim (Kuala Lumpur: Penerbit AIM, 1984), 13. 
mengikut satu piawaian yang telah ditetapkan. ${ }^{12}$ Kemiskinan relatif pula berkaitan dengan agihan pendapatan di mana tahap kecukupan keperluan asas minimum seseorang isi rumah dinilai berdasarkan perbandingan dengan tahap kecukupan keperluan asas minimum individu yang lain. ${ }^{13}$ Isu-isu kemiskinan ini adalah hal sejagat masyarakat seluruh dunia. Secara teori, kemiskinan ditakrifkan sebagai suatu keadaan individu yang mengalami masalah kekurangan untuk memenuhi keperluan hidup secara minimum. ${ }^{14}$ The Organisation for Economic Co-operation and Development (OECD) memberikan dimensi kekurangan yang boleh diklasifikasikan sebagai kemiskinan seperti 1) Keselamatan/Kecenderungan, 2) Keupayaan Ekonomi, 3) Keupayaan Manusia, 4) Keupayaan Sosial/Budaya dan; 5) Keupayaan politik. ${ }^{15}$

Keadaan hidup masyarakat di setiap negara berbeza-beza tentunya memberikan tafsiran yang berbeza terhadap konsep kemiskinan. Faktor kewangan dan kegagalan memenuhi keperluan material semata-mata tidak cukup untuk menilai tahap kemiskinan. Terdapat berbagai dimensi bagi menjelaskan konsep kemiskinan. Kepelbagaian dimensi aspek kekurangan turut diterima pakai dalam memberi pendefinisian kemiskinan. Oleh yang demikian, tidak ada satu takrif kemiskinan yang boleh diterima dan diguna pakai oleh semua negara pada setiap masa; tanpa mengambil kira struktur masyarakat dan tahap pembangunan di negara tersebut. Pentingnya isu kemiskinan diambil berat atas faktor pembangunan sesebuah ekonomi akan terjejas sekiranya ianya tidak ditangani dengan berkesan. Keadaan mati kelaparan, kekurangan makanan, penyakit dan kekurangan pendidikan dalam

12 Piawai ini dikenali sebagai Pendapatan Garis Kemiskinan (PGK). PGK ini ditentukan berasaskan kepada taraf hidup penduduk negara ini. PGK merupakan satu jumlah pendapatan minimum untuk membolehkan sesebuah isi rumah, secara purata, menampung keperluan makanan, pakaian dan perbelanjaan asas seperti sewa, bahan api dan tenaga, pengangkutan dan perhubungan, kesihatan dan rekreasi.

13 Kemiskinan relatif ini akan sentiasa wujud dan tidak mungkin dapat dihapuskan selagi mana wujud ketidakseimbangan dalam agihan pendapatan. Lagi tinggi ketidakseimbangan pendapatan lagi serius masalah kemiskinan relatif walaupun kemiskinan mutlak telah dibasmi sepenuhnya. Rujuk Norzita Jamil \& Siti Hadijah Che Mat, 'Realiti Kemiskinan: Satu Kajian Teoritikal', Jurnal Ekonomi Malaysia, vol. 48/1 (2014): 168.

14 Itang, 'Faktor-Faktor Penyebab Kemiskinan', Jurnal Keislaman, Kemasyarakatan dan Kebudayaan, vol. 16/1 (2015): 3.

15 Rachel Pain et. al., Introducing Social Geographies (London: Routledge, 2001), 25 . 
kalangan orang ramai boleh menyebabkan seseorang terjerumus ke lembah penjenayahan untuk menikmati hidup dalam kemewahan ${ }^{16}$ malah jika tidak dikawal dan dibasmi, isu ini mampu menjadi senjata yang menggugat kestabilan ekonomi dan politik sesebuah negara.

\section{KONSEP KEMISKINAN BANDAR}

Bandar ialah merupakan kawasan petempatan yang mempunyai ciriciri tertentu berbeza dari kawasan desa. Perbandaran adalah suatu proses perubahan status sama ada dari aspek penduduk, penempatan, cara hidup, pekerjaan, kegiatan ekonomi, pemikiran dan lain-lain ke arah yang lebih maju. ${ }^{17}$ Secara ringkasnya, definisi bandar bergantung kepada saiz penduduk dalam sesuatu penempatan yang mempunyai sempadan tertentu yang menjalankan perniagaan, perdagangan, perkhidmatan dan perindustrian. ${ }^{18}$ Ia merupakan suatu proses yang dinamik dan melibatkan pelbagai pola guna tanah di sesebuah kawasan pembangunan bandar. ${ }^{19}$

Seperti yang telah dijelaskan, kemiskinan adalah satu masalah kekurangan yang dihadapi oleh seseorang individu atau ahli isi rumah dalam meneruskan kehidupan seharian. Isu kemiskinan bandar juga berkait rapat dengan pengagihan kekayaan negara. Sebuah negara walaupun berpendapatan tinggi dengan pengagihan kekayaan yang tidak baik akan mempunyai ramai rakyatnya yang hidup di dalam kemiskinan bandar. Meskipun berbagai usaha yang dilakukan oleh banyak pihak untuk membasminya, namun ianya tetap berlaku. Mitlin (2003) mendapati sejumlah 495 juta golongan miskin bandar pada tahun 2000 adalah terdiri daripada golongan berpendapatan rendah dan sederhana. Fenomena ini memberi tamparan dan cabaran yang hebat kepada negara yang mengalaminya kerana ia mencetuskan berbagai permasalahan di bandar yang menjejaskan kualiti serta taraf hidup penduduk bandar. ${ }^{20}$

16 Nor Ghani Md. Nor, 'Dimensi Kemiskinan dan Rancangan Pembasmian Kemiskinan', dalam Siri Kumpulan Esei: Ekonomi Pembangunan, ed. Amir Hussin Baharuddin (Kuala Lumpur: Dewan Bahasa dan Pustaka, 1984), 21.

17 Katiman Rostam, Pengantar Geografi Bandar (Kuala Lumpur: Dewan Bahasa dan Pustaka, 1988), 35.

18 Katiman Rostam, Prinsip Asas Persekitaran Manusia (Bangi: Universiti Kebangsaan Malaysia, 2002), 61.

19 Shaharudin Ahmad, Mikroiklim Bandar: Perkembangan dan Impak Pulau Haba Bandar di Malaysia (Bangi: Universiti Kebangsaan Malaysia, 2012), 28.

20 Diana Mitlin, 'Addressing Urban Poverty through Strengthening Assets,' Habitat International, vol. 27/3 (2003): 341. 
Kemiskinan bandar adalah satu bentuk kemiskinan yang lebih terperinci dari konsep kemiskinan kerana ia merujuk kepada masalah kekurangan yang dihadapi oleh mereka bukan sahaja dari aspek kewangan semata-mata tetapi ia meliputi masalah kemiskinan yang bersifat pelbagai dimensi. ${ }^{21}$ Hal ini kerana, isu kekurangan yang wujud dalam kemiskinan bandar dipengaruhi oleh aspek-aspek lain yang menjadi faktor kepada tercetusnya keadaan miskin bandar seperti tempat tinggal, pendidikan, keselamatan sosial, infrastruktur dan perkhidmatan serta hak sosial. ${ }^{22}$

Kemiskinan bandar merujuk kepada masalah kekurangan yang dihadapi oleh seseorang dalam mencapai akses kepada peluang pekerjaan, pendapatan, perumahan yang selamat, persekitaran yang sihat, perlindungan sosial, peluang kesihatan dan peluang pendidikan. ${ }^{23}$ Tambahan pula, terdapat juga elemen lain yang diukur sebagai kemiskinan bandar iaitu kekurangan modal perniagaan yakni ekosistem keusahawanan yang lemah, pertumbuhan ekonomi atau perindustrian yang rendah di kawasan miskin bandar, diskriminasi kaum dan jantina, kurangnya modal politik dan suara dalam memberi pandangan. ${ }^{24}$ Kekurangan akses kepada perkara-perkara tersebut memberi kesan kepada tahap kepuasan dan kualiti hidup mereka.

Kemiskinan bandar tidak menggambarkan masalah kekurangan pada seseorang individu atau isi rumah semata-mata, tetapi ia merangkumi setiap masalah kekurangan yang wujud, sama ada dari aspek ekonomi, sosial, dan fizikal. Kemiskinan bandar adalah fenomena kemiskinan multidimensi dan merupakan sebab dan akibat daripada halangan yang terkumpul dan sukar di atasi. Kewujudan istilah kemiskinan bandar adalah lebih berfokus terhadap

21 Chriswardani Suryawati, 'Memahami Kemiskinan Secara Multidimensional,' Jurnal Manajemen Pelayanan Kesehatan, vol. 8/3 (2005), 125.

22 Ya Ping Wang, Urban Poverty Housing and Social Change in China (New York: Routledge, 2004), 57; Nasikun, 'Penanggulangan Kemiskinan: Kebijakan dalam Perspektif Gerakan Sosial', Jurnal Ilmu Sosial dan Ilmu Politik, vol. 6/1 (2002): 12; Om Prakash Mathur, Urban Poverty in Asian (Philippines: Asian Development Bank, 2014), 4.

23 Judy L. Baker, 'Urban Poverty: A Global View (English), 'Urban Paper, no. UP-5 (Washington, DC: World Bank, 2008), 28.

24 Alexandra M. Curley, 'Theories of Urban Poverty and Implications for Public Housing Policy,' Journal of Sociology and Social Welfare, vol. 32/2 (2005): 102; Michael B. Teitz \& Karren Chapple, 'The Causes of Inner-City Poverty: Eight Hypotheses in Search of Reality', Cityscape: A Journal of Policy Development and Research, vol. 3/3 (1998): 42. 
golongan miskin yang menetap di bandar kerana ia menerima kesan secara langsung daripada proses urbanisasi. ${ }^{25}$

Kemiskinan bandar tidak hanya merujuk kepada golongan yang menganggur, berpendapatan rendah, berpendidikan rendah, tempat tinggal yang daif serta tidak selamat, dan dihalang untuk menikmati segala kemudahan dan perkhidmatan di bandar, tetapi ia juga meliputi golongan yang berpendapatan baik, namun perlu menanggung kos perbelanjaan hidup melebihi dari jumlah pendapatan. ${ }^{26}$ Golongan ini boleh dikategorikan sebagai golongan kemiskinan relatif. Indikator dalam mengukur golongan ini sukar ditentukan dan memerlukan satu ukuran kemiskinan yang khusus dan bersifat komprehensif.

Kemiskinan bandar merupakan masalah sosio-ekonomi yang dihadapi oleh semua negara. Ianya bukan sahaja melanda negara-negara miskin seperti Bangladesh, India dan Nepal, malah menyerang negara-negara maju seperti Amerika Syarikat dan Jepun. Bagi sesetengah negara di wilayah Asia dan Pasifik khususnya di negara sedang membangun seperti China, India dan Indonesia, isu kemiskinan bandar telah menjadi fokus utama dalam inisiatif atau polisi pembangunan semenjak lebih dua dekad dahulu dan berbagai agenda telah diperkenalkan dan dipersetujui untuk mengatasinya meskipun sudahpun menjadi fokus secara langsung mahupun tidak langsung di dalam inisiatif-inisiatif pembangunan sejak di akhir era koloni antara tahun 1940-an hingga 1950 -an. ${ }^{27}$

\section{CIRI-CIRI KEMISKINAN BANDAR}

Secara umumnya, ciri-ciri kemiskinan sama ada di bandar mahupun luar bandar adalah berhadapan dengan masalah kekurangan dari aspek pendapatan, tiada pemilikan harta, taraf pendidikan yang rendah, persaingan yang sengit dalam

25 Mohd Fadzil Abdul Rashid \& Ishak Ab Ghani, 'Migrasi dan Kemiskinan Bandar: Suatu Kajian Literatur', (Kertas kerja, Seminar Kebangsaan Pembangunan Persekitaran \& Masyarakat 2007, Pulau Pinang, 17-18 Januari 2007), 7.

26 Zhou Xuejun, 'Voice of the Urban Poor' (Report on Participatory Urban Poverty Analysis in Beijing, Center for Integrated Agricultural Development (CIAD), 2000), 24.

27 UN ESCAP, 'Urban Poverty Alleviation', dalam Regional High-level Meeting in Preparation for Istanbul for Asia and the Pacific (Hangzhou: United Nations Centre for Human Settlements, 2000), 66. 
mendapatkan peluang pekerjaan di sektor formal. ${ }^{28}$ Walau bagaimanapun, kemiskinan bandar mempunyai sedikit perbezaan ciri-ciri yang wujud berbanding kemiskinan di luar bandar. Ciri-ciri kemiskinan bandar dapat dilihat melalui perbandingan antara insiden kemiskinan bandar dan luar bandar sepertimana berikut:

Pertama, di kawasan bandar, akses kepada segala jenis perkhidmatan telah disediakan oleh pihak kerajaan dan penduduk di bandar mempunyai peluang dan kesempatan untuk menikmatinya seperti sekolah, hospital, elektrik dan air, pekerjaan. Maka, mana-mana golongan yang berpendapatan rendah di bandar masih berpeluang untuk menikmati kemudah-kemudahan sosial ini namun perlu menghadapi bebanan perbelanjaan yang tinggi disebabkan faktor pendapatan yang terhad dan perbelanjaan yang lebih tinggi. Keadaan ini berbeza di luar bandar di mana akses kepada kemudahan asas dan sosial adalah terhad dan jauh. Hal ini akan menyukarkan golongan pendapatan rendah di luar bandar untuk mendapatkan akses kepada kemudahan ini dan kos perbelanjaan ini lebih rendah berbanding di kawasan bandar. ${ }^{29}$

Kedua, isu utama kemiskinan di bandar adalah disebabkan kos sara hidup yang tinggi di mana penduduk miskin di bandar perlu bekerja lebih untuk menambah pendapatan. Walaupun peluang pekerjaan di bandar adalah jauh lebih luas, namun atas faktor kelayakan pendidikan dan kemahiran yang rendah menyebabkan mereka menerima upah gaji yang rendah. Tambahan pula, masalah kemelesetan ekonomi negara akan menyukarkan mereka untuk mendapatkan bekalan makanan. Di kawasan luar bandar pula, peluang pekerja adalah terhad dan sukar untuk diperolehi. Penduduk di luar bandar perlu bekerja sendiri dan terlibat dalam sektor pertanian. Tambahan pula, kekurangan pengetahuan dan kemahiran untuk mengkomersialkan hasil produktivti mereka ke luar desa menyebabkan mereka terlalu bergantung dalam pasaran kampung yang terhad dan mengakibatkan pendapatan mereka tidak setimpal dengan usaha kerja yang dilakukan. ${ }^{30}$

28 Katiman Rostam, 'Kecekapan Ekonomi Ruang Bandar Versus Ketaksamaan Pembangunan di Malaysia: Suatu Pola Pembandaran dalam Era Perubahan Global', dalam Isu-Isu Semasa Alam Sekitar Manusia di Malaysia, ed. Yazid Saleh, Fauziah Che Leh \& Mazdi Marzuki (Tanjong Malim: Penerbit Universiti Pendidikan Sultan Idris, 2010), 7.

29 Lee Kok Chai \& Wan Rozali, 'Kualiti Hidup Sosial dan Isu-Isu Perumahan: Kajian Kes di Pulau Pinang', dalam Isu-Isu Semasa Alam Sekitar Manusia di Malaysia, ed. Yazid Saleh, Fauziah Che Leh \& Mazdi Marzuki, (Tanjong Malim: Penerbit Universiti Pendidikan Sultan Idris, 2010), 12.

30 Rawlins W.E. \& Dzurizah Ibrahim, 'Squatters at the Gateway of Urban Malaysia', in Sustainable Urban Development Issues in Malaysia, ed. Nurhaslina H. (Kuala Lumpur: Dewan Bahasa \& Pustaka, 2009), 32. 
Ketiga, golongan anak muda atau belia di bandar yang tidak mendapat pendidikan yang sewajarnya lebih cenderung untuk mencari pekerjaan walaupun dalam lingkungan umur yang rendah walaupun tidak mempunyai kelayakan pendidikan. Cabaran yang lebih membimbangkan apabila golongan anak muda sudah mempunyai pendapatan sendiri akan mendedahkan mereka kepada pelbagai masalah sosial jika tiak dipantau dengan baik. Hal ini berbeza dengan golongan anak muda di kawasan luar bandar. Kebanyakan daripada mereka yang keciciran dalam pendidikan akan memilih untuk tinggal di rumah sahaja dan mengharapkan tanggungan sepenuhnya daripada ibu bapa disebabkan oleh peluang untuk memajukan diri terbatas disebabkan oleh peluang pekerjaan yang rendah. ${ }^{31}$

Keempat, isu kemiskinan di kawasan luar bandar lebih mudah diselesaikan berbanding di kawasan bandar. Sebagai contoh projek-projek pertanian, pemasaran produk dan perumahan Projek Perumahan Rakyat Termiskin(PPRT) di desa dilihat lebih berupaya untuk menyelesaikan isu kemiskinan di kawasan luar bandar. Usaha ini dilihat tidak 'workable' untuk diimplementasikan terhadap isu kemiskinan di bandar melihatkan kepada cabaran kehidupan di bandar yang lebih tinggi dan rumit. Walau bagaimanapun, masih ada beberapa usaha lain yang mampu untuk membendung isu kemiskinan bandar seperti suntikan modal perniagaan secara kecil-kecilan seperti yang dilaksanakan oleh Projek Tekun. ${ }^{32}$

\section{FAKTOR-FAKTOR KEMISKINAN BANDAR}

Moser menjelaskan kemiskinan bandar tercetus akibat wujudnya pelbagai kekurangan secara jelas yang meliputi ketidakstabilan pendapatan sesuatu isi rumah yang membawa kepada ketidakcukupan. ${ }^{33}$ Risiko yang berpunca dari kegagalan mendapatkan kemudahan dan barang keperluan asas, perumahan yang berkualiti rendah membawa kepada risiko terdedah dengan masalah kesihatan, jenayah, bencana alam, dan diskriminasi serta kemudahan yang

31 Wan Rozali Wan Hussin, 'Kualiti Hidup Sosial dan Proses Perbandaran di Malaysia', dalam Isu-Isu Semasa Alam Sekitar Manusia di Malaysia, ed. Yazid Saleh, Fauziah Che Leh dan Mazdi Marzuki (Tanjong Malim: Penerbit Universiti Pendidikan Sultan Idris, 2010), 16.

32 Hassan N. Khalid, 'Satu Analisis Mengenai Dikotomi Antara kemiskinan Bandar dan Luar Bandar di Malaysia,' Perspektif: Jurnal Sains Sosial dan Kemanusiaan, vol. 4/1 (2012): 3 .

33 Caroline O.N. Moser, 'The Asset Vulnerability Framework: Reassessing Urban Poverty Reduction Strategies,' World Development, vol. 26/1 (1998), 8. 
disediakan kepada pasaran buruh adalah terhad kepada sesuatu jantina atau kumpulan etnik tertentu.

Terdapat pelbagai faktor yang membawa kepada kemiskinan bandar. Secara ringkas, faktor-faktor kemiskinan bandar adalah disebabkan oleh beberapa faktor seperti dalam jadual berikut. Perbahasan secara terperinci berhubung faktor-faktor ini dijelaskan dalam sub-topik yang seterusnya.

Jadual 1: Faktor-Faktor Kemiskinan Bandar

\begin{tabular}{|c|c|}
\hline Faktor & Huraian \\
\hline $\begin{array}{l}\text { Peluang pekerjaan } \\
\text { yang terhad }\end{array}$ & $\begin{array}{l}\text { Lebihan tenaga kerja yang banyak dari pelbagai peringkat } \\
\text { kemahiran dan tahap kelayakan di bandar menyebabkan } \\
\text { sektor bandar sukar untuk menyediakan peluang peker- } \\
\text { jaan, walaupun ia sangat terhad. Situasi ini mewujudkan } \\
\text { persaingan dan yang gagal menjadi golongan mengang- } \\
\text { gur, hilang pekerjaan dan tidak mempunyai pekerjaan. }\end{array}$ \\
\hline
\end{tabular}

Pendapatan tidak Penghidupan di bandar terpaksa melalui kos sara hidup mampu menanggung keperluan asas (perumahan, makanan, pakaian, pendidikos sara hidup kan, kesihatan) yang tinggi. Oleh itu, golongan yang berpendapatan rendah, walaupun di atas PGK keseluruhan masih tidak mampu untuk menanggung kos kehidupan tersebut.

Perumahan di bandar Harga rumah di bandar adalah tinggi dan tidak mampu dimilik mahupun untuk disewa oleh golongan penduduk yang berpendapatan rendah. Perumahan kos rendah pula adalah terhad. Situasi ini selalunya mewujudkan penempatan setinggan dan golongan miskin bandar.

Kelemahan sistem Kelemahan sistem pengakutan bandar boleh menghalang pengangkutan penduduk bandar untuk akses kepaada peluang ekonomi, kemudahan dan perkhidmatan. Ini meningkakan kos perbelanjaan isi rumah kerana terpaksa berbelanja untuk kos pengangkutan yang tinggi. Oleh itu, akses kepada sistem pengangkutan mampu mengurangkan kemiskinan bandar malah membantu menggiatkan lagi kegiatan ekonomi bandar melalui penglibatan penduduk sama ada di sektor formal dan informal di bandar. 


\begin{abstract}
Faktor
Huraian

Persekitaran fizikal Kemiskinan bandar juga saling mempunyai perkaitan dengan persekitaran fizikal kerana persekitaran fizikal bandar yang tidak sihat akan mendedahkan penduduk kepada pelbagai gejala penyakit. Ini menyebabkan penggunaan wang untuk perbelanjaan rawatan dan penjagaan kesihatan yang akan mengurangkan simpanan. Oleh itu, meningkatkan kualiti persekitaran bandar secara langsung ataupun tidak langsung membantu mengurangkan kemiskinan.

Globalisasi

Di negara-negara sedang membangun khususnya, globalisasi meluaskan lagi jurang perbezaan di antara golongan senang dan susah dalam kalangan masyarakat bandar. Golongan yang mempunyai modal dan mampu akses kepada berbagai informasi dan berkeupayaan menterjemahkannya kepada manfaat ekonomi, politik, ekonomi, dan sosial akan mendapat faedah daripada globalisasi. Manakala golongan yang tidak mampu dan lemah akan lebih terpinggir dan miskin. Globalisasi juga memaksa kerajaan terutama di negara-negara membangun menstrukturkan kembali sistem ekonomi supaya lebih kompetatif di dalam pasaran global dengan cara 'rightsizing government' dan mengurangkan subsidi dan pengswastaan. Ini menyebabkan pengurangan peruntukan terutama terhadap bantuan pendidikan dan kesihatan, yang menyebabkan pengurangan terhadap perkhidmatan untuk golongan miskin.
\end{abstract}

Halangan sosial dan Taraf pendidikan yang rendah mendorong berlakunya psikologi kemiskinan bandar kerana pasaran buruh yang kompetatif memerlukan individu yang mempunyai pendidikan dan kemahiran yang tinggi. Golongan berpendidikan rendah juga selalunya kurang motivasi untuk berjaya. Tambahan pula, kanak-kanak daripada keluarga miskin tidak mampu untuk akses kepada kemudahan pendidikan yang sempurna berbanding dengan kanak-kanak daripada golongan berada dan kebanykan mereka berhenti sekolah lebih awal untuk membantu menambah kewangan keluarga. 
Faktor

Faktor-faktor lain

\section{Huraian}

Kenaikan harga barang keperluan asas khususnya barangan makanan dan minyak kenderaan, pengurangan subsidi terhadap kemudahan pendidikan dan kesihatan dan inflasi akan meningkatkan lagi kemiskinan bandar kerana kadar perbelanjaan lebih tinggi daripada jumlah pendapatan.

Sumber: Mohd Fadzil Abdul Rashid dan Ishak Ab Ghani. ${ }^{34}$

Banyak kajian-kajian lepas mengaitkan insiden kemiskinan bandar ini berlaku disebabkan oleh isu kekurangan modal insan seperti pendidikan formal dan kemahiran tidak formal. ${ }^{35}$ Hal ini tidak menghairankan kerana modal insan sering dijadikan penanda aras tahap pekerjaan yang dimiliki untuk meraih pendapatan. Selain itu, faktor identiti demografi asal usul juga dijadikan sebagai petunjuk penting dalam mengklasifikasikan seseorang itu sebagai miskin bandar kesan daripada berlakunya migrasi ke bandar. ${ }^{36}$ Terdapat juga elemen-elemen lain seperti faktor kewangan ${ }^{37}$ (pendapatan), pemilikan rumah $^{38}$ dan pertumbuhan jumlah penduduk ${ }^{39}$ sebagai elemen penting dalam mengklasifikasikan seseorang sebagai miskin bandar.

Antara permasalahan lain yang lazimnya timbul impak daripada kemiskinan bandar adalah masalah seperti setinggan bandar, kemiskinan, peningkatan kes jenayah dan masalah sosial seperti rogol, sumbang mahram,

34 Mohd Fadzil Abdul Rashid \& Ishak Ab Ghani, 'Migrasi dan Kemiskinan Bandar: Suatu Kajian Literatur', 7-8; David Satterthwaite, 'Reducing Urban Poverty: Constraints on the Effectiveness of Aid Agencies and Development Banks and Some Suggestions for Change,' Environment and Urbanization, vol. 13/1 (2001), 141.

35 T.Y. Mok, C. Gan \& A. Sanyal, 'The Determinants of Urban Household Poverty in Malaysia', Journal of Social Sciences, vol. 3/4 (2007):193.

36 T.Y. Mok, C. Gan \& A. Sanyal, 'The Determinants of Urban Household Poverty in Malaysia', 195.

37 Wan Nor Azriyati Wan Abd Aziz et al., 'Pembasmian Kemiskinan Bandar ke Arah Bandar Inklusif Sejahtera: Cabaran Kuala Lumpur', Journal of Surveying, Construction and Property, vol. 2/1 (2011): 18.

38 Selamah Abdullah Yusof, Rohaiza Abd Rokis \& Wan Jamaliah Wan Jusoh, 'Financial Fragility of Urban Households in Malaysia', Jurnal Ekonomi Malaysia, vol. 49/1 (2015): 19.

39 Siwar Chamhuri et al., 'Urbanization and Urban Poverty in Malaysia: Consequences and Vulnerability', Journal of Applied Sciences, vol. 16/4 (2016): 157. 
pembunuhan, penurunan taraf kesihatan dan tahap keselamatan, pengabaian terhadap pendidikan dan kesihatan anak-anak serta berbagai permasalahan alam sekitar khususnya berkaitan dengan pencemaran. Oleh itu, kemiskinan bandar menyebabkan penduduk sentiasa berhadapan dengan keadaan yang tidak selamat sama ada di dalam mahupun di luar tempat tinggal. Lebih dari itu, berbagai masalah yang dicetuskan oleh kemiskinan bandar ini juga saling mempengaruhi di antara satu dengan yang lain dan akan menjadi lebih besar jika isu ini tidak dapat ditangani dengan baik.

Berasaskan konsep dan definisi umum kemiskinan yang dibincangkan di atas, maka dapatlah difahami bahawa definisi kemiskinan bandar bukan hanya merujuk kepada individu atau sesebuah isi rumah yang miskin (golongan miskin bandar), malahan merangkumi sekali sebarang kekurangan yang dimiliki individu terbabit dan keadaan persekitaran ekonomi, sosial dan fizikal di sekitarnya yang mempunyai kekurangan (antaranya peluang pekerjaan dan pendapatan rendah, kelemahan penyediaan kemudahan infrastruktur, prasarana asas dan perkhidmatan, terdedah kepada persekitaran tidak selamat) ataupun kemampuan untuk menikmati kemudahan dan perkhidmatan yang disediakan sangat terhad. Ini menjelaskan bahawa kemiskinan bandar adalah multi-dimensi fenomena dan sebab akibat daripada halangan yang bersifat kumulatif serta sukar di atasi. Walaupun begitu, memberi definisi kemiskinan bandar terhadap golongan miskin bandar adalah munasabah dan secara umumnya dapat diterima kerana golongan ini yang mencetus dan menerima kesan langsung daripada kewujudan kemiskinan bandar. ${ }^{40}$

\section{KEMISKINAN MENURUT PANDANGAN ISLAM}

Pengukuran kemiskinan dalam Islam boleh dipecahkan kepada dua istilah, iaitu fakir dan miskin. Istilah fakir menurut Muhammad al-Husayni ${ }^{41}$ dan Wahbah al-Zuhayli ${ }^{42}$ didefinisikan sebagai seseorang individu yang tidak memiliki sebarang pekerjaan atau harta sehingga mengakibatkan mereka tidak mampu umtuk memenuhi keperluan asas hidup termasuk yang sudah mempunyai ahli keluarga atau tanggungan yang tidak mencukupi keperluan nafkahnya. Istilah miskin pula merujuk kepada seseorang individu yang memiliki pekerjaan untuk memperolehi pendapatan bagi menampung keperluan hidupnya sama

\footnotetext{
40 Mohd Fadzil Abdul Rashid \& Ishak Ab Ghani, 'Migrasi dan Kemiskinan Bandar: Suatu Kajian Literatur', 4.

41 Al-Hisān̄̄, Taqī al-Dīn, Ab̄̄ Bakr bin Muhammad al-Husayn̄̄, Kifāyah al-Akhyār fì Halli Ghāyah al-Ikhtișār (Bayrūt: Dār al-Kutub al-'Ilmiyyah, 2001), 277-278.

42 Wahbah al-Zuhaylī, al-Fiqh al-Islāmī wa Adillatuh, vol. 2 (Dimashq: Dār al-Fikr, 1985), 869.
} 
ada secara sendiri atau mempunyai ahli keluarga atau tanggungan. Walau bagaimanapun, hasil pendapatan yang diperolehi tidak mencukupi untuk menampung keperluan hidup mereka. Keperluan hidup yang perlu dipenuhi dalam suatu keadaan semasa merangkumi makanan, minuman, pakaian dan tempat tinggal. ${ }^{43}$

Menurut definisi daripada Muhammad Rawwās Qal'ajīi, ${ }^{44}$ seseorang itu dikategorikan sebagai fakir apabila memiliki harta pada jumlah yang sedikit daripada kadar 40 dirham (RM800) atau 1 uqiah $^{45}$ (4 dinar) dalam menampung keperluan asas hidup. Miskin pula apabila seseorang yang memiliki keperluan hidup yang lebih besar berbanding jumlah pendapatan yang diperolehi dari hasil pekerjaannya. Berdasarkan definisi di atas, seseorang yang dikategorikan sebagai fakir mempunyai taraf hidup yang lebih teruk berbanding seseorang yang berada dalam kategori miskin masih mampu untuk memenuhi keperluan hidup walau pun mempunyai taraf hidup yang rendah. Hal ini bertepatan dengan firman Allah SWT sepertimana berikut:

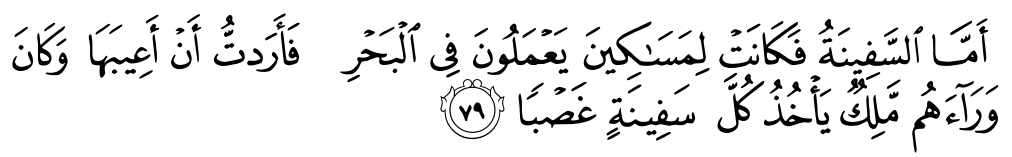

“Adapun perahu itu adalah ia dipunyai oleh orang-orang miskin yang bekerja di laut, oleh itu, aku bocorkan dengan tujuan hendak mencacatkannya, kerana di belakang mereka nanti ada seorang raja yang merampas tiap-tiap sebuah perahu yang tidak cacat."

(Surah al-Kahfī, 18: 79)

Berdasarkan firman Allah SWT di atas, pada ayat "adapun perahu itu adalah ia dipunyai oleh orang-orang miskin yang bekerja di laut" menjelaskan bahawa golongan miskin masih mempunyai harta walaupun sedikit berbanding golongan fakir yang tidak memiliki sebarang harta seperti dalam firman Allah SWT yang berikut:

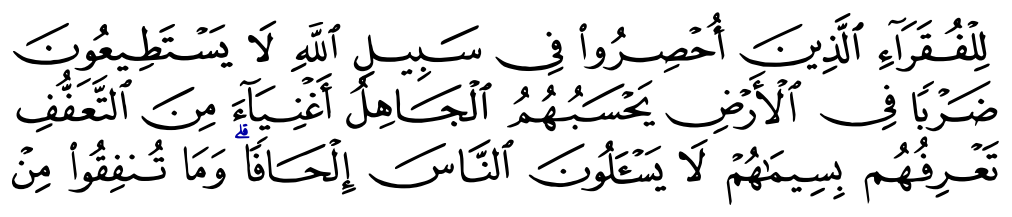

\footnotetext{
43 Wahbah al-Zuhạalī, al-Fiqh al-Istāmī wa Adillatuh, vol. 2, 866-870.

44 Muḥammad Rawwās Qal'ajī, Mawsū'ah Fiqh 'Umar bin al-Khatṭāb (Bayrūt: Dār al-Nafash, 1989), 469.

45 Sayed Afzal Peerzade, 'The Definition and Measurement of Poverty: An Integrated Islamic Approach', The Pakistan Development Review, vol. 36/1 (1997): 91.
} 


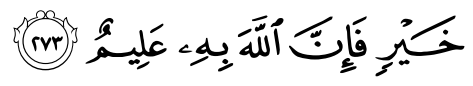

"(Pemberian sedekah itu) ialah bagi orang-orang fakir miskin yang telah menentukan dirinya (dengan menjalankan khidmat atau berjuang) pada jalan Allah (membela Islam), yang tidak berupaya mengembara di muka bumi (untuk berniaga dan sebagainya); mereka itu disangka: orang kaya - oleh orang yang tidak mengetahui halnya, kerana mereka menahan diri daripada meminta-minta. Engkau kenal mereka dengan (melihat) sifatsifat dan keadaan masing-masing, mereka tidak meminta kepada orang ramai dengan mendesak-desak. Dan (ketahuilah), apa jua yang kamu belanjakan dari harta yang halal maka sesungguhnya Allah sentiasa Mengetahuinya."

(Surah al-Baqarah, 2: 273)

Berdasarkan ayat di atas, perkataan li al-fuqara' adalah membawa maksud orang-orang fakir. Perkataan fuqara' adalah jama' kepada perkataan faqir ( mufrad). Ini bermakna, golongan fakir adalah mereka yang tidak mempunyai keupayaan dan kemampuan untuk berusaha untuk memperolehi sesuatu harta atau pendapatan. Selain itu, menurut Imam Ghazali RA, ${ }^{46}$ fakir didefinisikan sebagai mereka yang tidak mempunyai apa-apa harta dan mengharapkan kepada sesuatu harta untuk meneruskan kehidupan. Definisi ini selari dengan firman Allah SWT di dalam al-Quran:

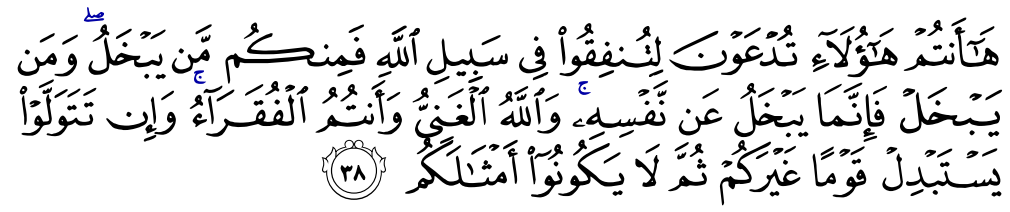

"(Ingatlah), kamu ini adalah orang-orang yang bertabiat demikian - kamu diseru supaya menderma dan membelanjakan sedikit dari harta benda kamu pada jalan Allah, maka ada di antara kamu yang berlaku bakhil, padahal sesiapa yang berlaku bakhil maka sesungguhnya ia hanyalah berlaku bakhil kepada dirinya sendiri. Dan (ingatlah) Allah Maha kaya (tidak berhajat kepada sesuatupun), sedang kamu semua orang-orang miskin (yang sentiasa berhajat kepadaNya dalam segala hal). Dan jika kamu berpaling (daripada beriman, bertaqwa dan berderma) Ia

46 Al-Ghazzālī, Abū Hamīd Muḥammad Ibn Aḥmad, Ihyā' 'Ulūm al-Dīn, vol. 7 (Indonesia: Penerbit Asli, 1988), 96. 
akan menggantikan kamu dengan kaum yang lain; setelah itu mereka tidak akan berkeadaan seperti kamu."

(Surah Muhammad, 47: 38)

Ayat di atas jelas menunjukkan bahawa manusia pada asalnya dikategorikan sebagai fakir kerana tidak memiliki apa-apa dan memerlukan sesuatu, manakala segala kekayaan yang wujud adalah milik Allah SWT secara mutlak. Istilah alfuqara dalam ayat di atas merujuk kepada manusia yakni makhluk yang tidak memiliki apa-apa kecuali semuanya adalah milik Allah SWT. ${ }^{47}$ Tambahan pula, Imam al-Ghazali menjelaskan maksud miskin yang merujuk kepada perbuatan seseorang yang menyembunyikan kesusahannya tanpa meminta-minta kepada sesiapa sepertimana dalam hadis Rasulullah SAW sepertimana berikut:

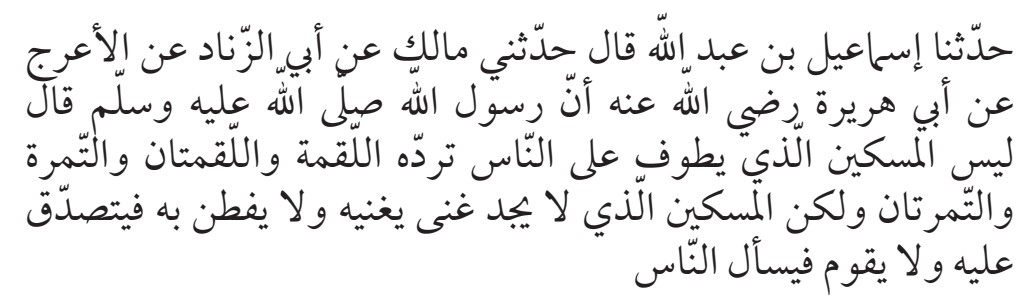

"Telah menceritakan kepada kami Ismā 'ìl bin 'Abd Allāh berkata, telah menceritakan kepada saya Mālik dari Abū al-Zanād dari al-A 'raj, daripada Abū Hurayrah RA bahawa Rasulullah SAW bersabda: Orang miskin itu bukanlah orang yang berkeliling meminta-minta kepada manusia, lalu ia diberikan sesuap dua suap, sebuah dan dua biji kurma. Para sahabat bertanya kalau begitu siapakah orang miskin itu wahai Rasulullah. Rasulullah SAW bersabda: Orang yang tidak menemukan harta yang mencukupinya tapi orang-orang tidak tahu kerana kesabarannya, ia menyembunyikan keadaannya dan tidak meminta-minta kepada orang lain, lalu diberi sedekah tanpa meminta sesuatu pun kepada manusia." 48

47 Abdul Rahman Talib \& Hasan Ahmad, 'Penilaian Kelayakan Asnaf Fakir dan Miskin Berdasarkan Had Kifayah,' International Journal of Humanities Technology and Civilization, no. 5 (2019), 298-306.

48 Hadis riwayat Muslim. Kitāb al-Zakāh, bāb al-Miskīn Alladh̄̄ la Yajidu Ghann̄̄ wala Yaftinū lahū Fayatasaddaku Alayh, no. hadis 1039. Lihat Muslim, Abī alḤusayn Muslim Ibn al-Ḥajjāj Ibn al-Qushayrī al-Naysabūrī, Șaḥịh Muslim bi Sharḥ al-Imām Muhy al-Dīn al-Nawawì (Bayrūt: Dār al-Kutub 'Ilmiyyah, 1991), 719; Hadis riwayat al-Bukhārī, "Kitāb al-Zakāh, Bāb Qawl Allāh Ta'āla: La Yas'alū alNās Ilhāfan," no. hadis 1479. Lihat al-Bukhārī, Abī "Abd Allāh Muhammad Ibn Ismā'īl al-Ju'fī, Șaḥịh al-Bukhārī (Bayrūt: Dār Ibn Kathīr, 2002), 360-361. 
Berdasarkan hadis di atas, golongan miskin adalah golongan manusia yang tidak mengetahui kemiskinan yang dialami olehnya kerana sifat sabar dan menyembunyikan kesusahan yang dialami oleh mereka. Secara umumnya, istilah fakir dan miskin mempunyai konsep yang sama, iaitu mengalami masalah kekurangan dalam memenuhi keperluan hidup. Walau bagaimanapun, kedua-dua istilah ini dapat dibezakan melalui tahap kritikal dalam masalah kekurangan yang dihadapi oleh kedua-dua golongan ini.

\section{KEMISKINAN MENURUT EMPAT MAZHAB UTAMA}

Shāfi'iyyah menjelaskan fakir diertikan sebagai individu yang tidak memiliki sebarang harta dan pekerjaan atau memiliki harta dan pekerjaan lebih sedikit daripada keperluan terhadap dirinya dan tanggungannya. Ia memerlukan 10 dirham (RM200.00) bagi memenuhi keperluan asas hidupnya, namun hanya memiliki 2 dirham (RM40) sahaja. ${ }^{49}$ Tambahan pula, golongan fakir dikategorikan sebagai golongan yang lebih susah daripada miskin. Selain itu, konsep kemiskinan yang dijelaskan oleh Shāfi'iyyah menganggap bahawa ia merupakan satu permasalahan multidimensi di mana seseorang yang berada dalam keadaan miskin wajib diberi bantuan dalam bentuk agihan zakat sehingga memenuhi keperluan asas dalam kehidupannya. Keperluan asas dalam kehidupan menurut pandangan Shāfi'iyyah adalah dalam bentuk makanan, minuman dan pakaian. ${ }^{50}$

Al-Shāfi'iyyah mendefinisikan kemiskinan sebagai seseorang yang memiliki harta dan pekerjaan, namun hanya mampu untuk memenuhi keperluan hidupnya sebanyak 7 dirham (RM140.00) daripada 10 dirham (RM200.00) dalam memenuhi keperluan hidup. ${ }^{51}$ Berdasarkan pandangan ini, istilah fakir dan miskin mempunyai ciri-ciri pendefinisian yang berbeza walaupun secara asasnya kedua-dua istilah ini menjelaskan isu kekurangan dalam hidup. Fakir mempunyai ciri-ciri ketidakupayaan untuk bekerja dan memiliki harta dan tidak mempunyai sebarang bentuk harta. Manakala miskin pula mempunyai ciri-ciri keupayaan untuk bekerja dan memiliki harta, namun hasil pendapatan dan harta yang diperolehi tidak mampu untuk memenuhi keperluan hidup secara menyeluruh.

49 Al-Hisān̄̄, Taqū al-Dīn, Abī Bakr bin Muhammad al-Husaynī, Kifāyah al-Akhyār fì Halli Ghāyah al-Ikhtișār, 277-278.

50 Al-Shāfi'ī, Abū 'Abd Allāh Muḥammad Ibn Idrīs, al-Umm (Riyāḍ: Bayt al-Afkār al-Dawliyyah, t.t.), 282.

51 Al-Shirāzī, Abū Isḥāq Ibrāhīm Ibn ‘Alī Ibn Yūsuf al-Fayrūz Abādī, al-Muhadhdhāb fì al-Fiqh al-Imām al-Shāfi ‘ '̀ (Bayrūt: Dār al-Kutub al-'Ilmiyyah, t.t.), 1:2-4-215. 
Hanābilah ${ }^{52}$ mempunyai pandangan yang sama dengan Shāfi'iyyah, di mana beliau berpendapat kemiskinan adalah keadaan apabila seseorang itu tidak mempunyai atau memiliki apa-apa. Golongan fakir ditakrifkan sebagai mereka yang tidak mempunyai apa-apa atau tidak memiliki separuh daripada keperluan hidup, manakala golongan miskin pula adalah mereka yang hanya mampu memenuhi sebahagian atau lebih separuh sahaja daripada keperluan hidup. Berdasarkan kedua-dua pandangan mazhab ini, golongan fakir dilihat mempunyai taraf hidup yang lebih susah berbanding golongan miskin dalam soal memenuhi keperluan hidup.

Walau bagaimanapun, terdapat perbezaan definisi dalam mazhab Mālikiyyah. Menurut pandangan Mālikiyyah, ${ }^{53}$ kemiskinan dilihat sebagai ketidakupayaan seseorang untuk bekerja dan memiliki harta bagi memenuhi keperluan hidup. Pandangan Mālikiyyah tentang pendefinisian golongan fakir adalah mereka yang memiliki harta yang sedikit daripada keperluan umum, namun masih tidak mampu untuk memenuhi keperluan hidup secara keseluruhan. Manakala golongan miskin pula adalah mereka yang tidak memiliki apa-apa. Kesimpulan daripada pandangan Mālikiyyah adalah golongan miskin mempunyai kedudukan dan tahap yang lebih teruk berbanding golongan fakir dalam konteks keupayaan untuk memenuhi keperluan hidup

Tambahan pula, Hanāfiyyah ${ }^{54}$ juga mempunyai pandangan yang sama dengan Mālikiyyah, di mana fakir adalah individu yang memiliki harta yang sedikit daripada niṣāb harta atau memiliki harta yang mencukupi dari niṣāb harta, namun masih tidak mencukupi untuk memenuhi keperluan hidup mereka. Manakala miskin pula adalah mereka yang tidak memiliki sebarang harta. Selain itu, Hanāfiyyah juga berpendapat bahawa fakir adalah orang yang tidak meminta-minta, manakala miskin pula adalah mereka yang sering meminta. ${ }^{55}$ Secara mudahnya, fakir adalah mereka yang masih mampu memenuhi sebahagian daripada keperluan hidup dan miskin pula tidak mempunyai apa-apa.

Ringkasnya, pandangan Shāfi'iyyah mempunyai persamaan dengan pandangan Hanābilah tentang definisi fakir dan miskin di mana golongan fakir

52 'Abd Allāh bin Aḥmad bin Qudāmah, al-Kāfì fí al-Fiqh Hanbāl (t.t.p.: al-Maktabah al-Islāmī, 1988), 423.

53 Muhammad bin Aḥmad bin Jaz̄̄ al-Kalbī al-Gharnatī, al-Qawānīn al-Fiqhiyyah li Ibn Jazī (Bayrūt: Dār al-Kutub, 1998), 74.

54 Muhy al-Dīn 'Abd al-Hamīd, Sabīl al-Fallāh fì Nūr al-Lidah (Bayrūt: Dār alBayrūtī, t.t.), 225-226.

55 Al-Shayban̄̄, Ab̄̄ 'Abd Allāh Muhammad bin al-Hasan, al-Jamī' al-Ṣaghīr (Pakistan: Idārah al-Qur’ān wa al-'Ulūm al-Islāmiyyah, 1990), 124. 
dilihat mempunyai kedudukan yang lebih susah berbanding golongan miskin. Manakala Mālikiyyah dan Ḥanāfiyyah bersepakat bahawa golongan miskin mempunyai kedudukan yang lebih susah berbanding golongan fakir dalam soal pemenuhan keperluan hidup.

Secara umumnya, ulama fiqh meletakkan indikator pemenuhan keperluan kehidupan yang perlu dipenuhi dengan mencirikan berdasarkan daripada istilah fakir dan miskin sahaja tanpa ditentukan jumlah kadar niṣāb keperluan hidup seharian. Hal ini kerana aspek keperluan hidup sentiasa berubahubah dan berkembang mengikut keadaan masa dan perkembangan zaman. Bahkan, kadar niṣāb adalah berbeza mengikut wilayah, budaya kehidupan dan perubahan aspek keperluan hidup, didorong oleh kewujudan keperluankeperluan baru dari semasa ke semasa.

\section{FALSAFAH PEMBANGUNAN EKONOMI MENURUT ISLAM}

Terdapat empat dasar dalam falsafah pembangunan ekonomi yang memberi penekanan kepada isu kemiskinan untuk mencapai kemaslahatan di dunia dan di akhirat: 56

\section{Tauhid}

Konsep tauhid merupakan tunjang utama dalam setiap perihal sesuatu perkara termasuk dalam aspek pembangunan ekonomi kerana ia didasari dengan kepatuhan pada setiap perancangan Allah SWT yang melibatkan hubungan antara manusia dengan Allah SWT dan hubungan manusia sesama manusia.

\section{Rububiyyah}

Konsep rububiyyah merupakan perincian daripada hukum-hukum yang telah ditetapkan oleh Allah SWT agar setiap model pembangunan ekonomi perlu berlandaskan prinsip Islam. Konsep ini merupakan satu panduan yang komprehensif dalam membangunkan sumber manusia agar manusia saling bantu-membantu antara satu sama lain.

$\overline{56}$ Kurshid Ahmad, 'Economic Development in An Islamic Framework', dalam Studies in Islamic Economics, ed. Kurshid Ahmad (Leicester: Islamic Foundation, 1980), 178-179. 


\section{Khilafah}

Konsep khilafah menjelaskan tentang peranan manusia yang bertanggungjawab untuk memakmurkan alam yang dicipta oleh Allah SWT dan berperanan sebagai pemegang amanah Allah SWT dalam menguruskan setiap hasil-hasil yang dikurniakan oleh Allah SWT secara adil dan saksama.

\section{Tazkiyyah}

Konsep tazkiyyah adalah bersifat menyucikan manusia antara hubungan dengan Allah dan sesama makhluk yang lain. Dalam konteks pembangunan ekonomi, keseimbangan antara peranan pemerintah dan rakyat merupakan jalan tazkiyyah dalam mencapai kemakmuran ekonomi.

\section{PERANAN PEMERINTAH DAN RAKYAT DALAM PEMBASMIAN KEMISKINAN BANDAR}

Dalam menangani permasalahan kemiskinan bandar, peranan dua hala yang melibatkan pemerintah dan rakyat perlu dimainkan agar proses pembangunan bandar dapat dilaksanakan, di samping tidak mengabaikan taraf ekonomi rakyat. Maka, inisiatif yang boleh diambil oleh kerajaan bagi menangani masalah kemiskinan bandar adalah melalui strategi pembasmian kemiskinan bandar.

\section{Peranan Pemerintah ${ }^{57}$}

Melalui strategi pembasmian kemiskinan bandar, pemerintah harus berperanan untuk melaksanakan sistem ekonomi yang bersifat mengangkat martabat taraf ekonomi masyarakat terutamanya kelas ekonomi yang rendah. Ini bermakna, dalam proses pembangunan bandar perlu ditekankan terhadap penyediakan peluang pekerjaan, kemudahan pendidikan, kesihatan, telekomunikasi, dan pengangkutan yang mampu meningkatkan produktiviti sumber manusia. Selain itu, kerajaan juga perlu menyediakan peluang-peluang latihan kemahiran kepada golongan masyarakat yang tidak berkemampuan untuk mencungkil bakat diri dan potensi mereka sehingga memberi sumbangan kepada pembangunan pembandaran seperti pinjaman atau pembiayaan terhadap sesuatu program pembangunan kemahiran.

57 Nina Herlina \& Mamay Komariah, 'Peran Pemerintah dalam Pengentasan Kemiskinan Kabupaten Ciamis', Jurnal Ilmiah Galuh Justisi, vol. 5/2 (2017): 267-269. 


\section{Peranan Rakyat ${ }^{58}$}

Dari sudut peranan yang dimainkan oleh rakyat pula, persepsi rakyat terhadap kemiskinan perlu diubah dan diperbetulkan semula. Rakyat perlu memahami konsep teologi kemiskinan dan mempunyai kesedaran dalam membasmi kemiskinan.

\section{a) Pemahaman Semula Teori Kemiskinan}

Pemahaman semula teologi kemiskinan ini merujuk kepada perubahan sosial. Perubahan sosial perlu dimulakan dengan perubahan individu yang melibatkan kaedah berfikir, motivasi, pandangan hidup, dan lain-lain. Jika sebelum ini umat Islam menganggap kemiskinan yang berlaku terhadap diri mereka adalah ujian daripada Allah SWT semata-mata, maka mereka perlu mengubah pandangan mereka tentang kemiskinan yang bukan hanya ujian semata-mata dan perlu redha dengan apa yang berlaku, tetapi lebih kepada berusaha untuk keluar dari cengkaman kemiskinan dengan berpegang pada sifat Allah SWT yang pemurah dan memberi rezeki. Hal ini bertepatan dengan firman Allah SWT di dalam al-Quran:

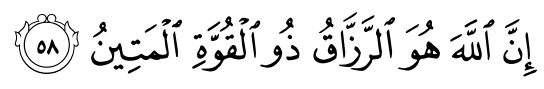

"Sesungguhnya Allah maha pemberi rezeki yang mempunyai kekuatan lagi sangat kukuh”.

(Surah al-Dhāriyāt, 51: 58)

Selain itu, umat Islam perlu sedar akan tujuan kehidupan di muka bumi ini yang berfungsi sebagai khalifah untuk memakmurkan bumi tuhan. Ini bermakna manusia memiliki kuasa ke atas diri mereka dan mampu untuk melakukan perubahan pada diri mereka sepertimana firman Allah SWT di dalam al-Quran:

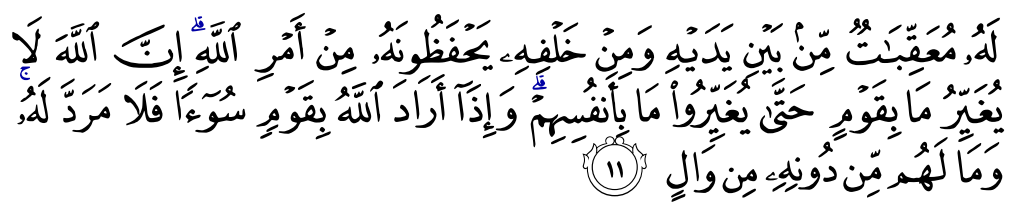

"Bagi manusia ada malaikat-malaikat yang selalu mengikutinya bergiliran, di muka dan di belakangnya, mereka menjaganya

58 Nina Herlina \& Mamay Komariah, 'Peran Pemerintah dalam Pengentasan Kemiskinan Kabupaten Ciamis', 271. 
atas perintah Allah. Sesungguhnya Allah tidak merubah keadaan sesuatu kaum sehingga mereka merubah keadaan yang ada pada diri mereka sendiri. Dan apabila Allah SWT menghendaki keburukan terhadap sesuatu kaum, maka tak ada yang dapat menolaknya; dan sekali-kali tak ada pelindung bagi mereka selain Dia."

(Surah al-Ra'd, 13: 11)

\section{b) Pembangunan Kesedaran Kolektif Pembasmian Kemiskinan ${ }^{59}$}

Kesedaran individu tentang pembasmian kemiskinan merupakan instrumen yang penting. Hal ini kerana, al-Quran menggalakkan manusia untuk membina pembentukan peribadi yang mulia, dermawan dan sanggup berkorban. Hal ini mendidik manusia bahawa usaha membasmi kemiskinan atau menolong golongan miskin adalah kewajipan orang kaya kerana di dalam hartanya ada hak orang lain iaitu orang miskin. Oleh itu membantu orang miskin adalah satu kewajipan sebagaimana dinyatakan oleh Allah SWT dan Nabi SAW. Mengenepikan hak orang miskin dianggap sebagai kesalahan di sisi agama. Firman Allah SWT:

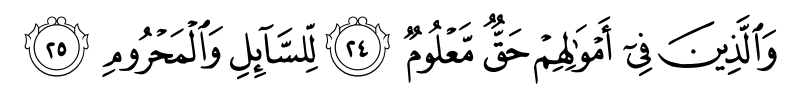

"Dan di dalam harta mereka terdapat hak bagi orang miskin yang meminta dan yang tidak meminta."

(Surah al-Ma‘ārij, 70: 24-25)

Selain itu, terdapat firman Allah SWT yang menjanjikan balasan yang besar kepada mana-mana individu yang mendermakan hartanya kepada sesama manusia terutama kepada golongan-golongan miskin. Allah SWT berfirman yang bermaksud:

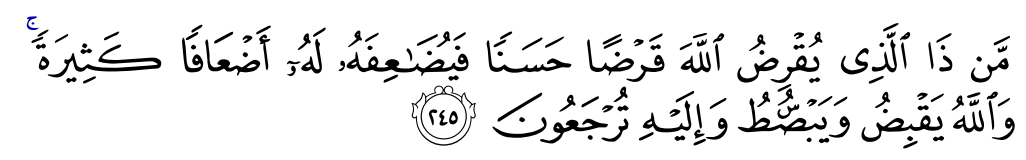

"Siapakah yang mahu memberi pinjaman kepada Allah, pinjaman yang baik (menafkahkan hartanya di jalan Allah), maka Allah akan memperlipat gandakan pembayaran kepadanya

59 Nina Herlina \& Mamay Komariah, 'Peran Pemerintah dalam Pengentasan Kemiskinan Kabupaten Ciamis’, 272. 
dengan lipat ganda yang banyak. Dan Allah menyempitkan dan melapangkan (rezeki) dan kepadaNyalah kamu dikembalikan."

(Surah al-Baqarah, 2: 245)

Berdasarkan ayat di atas, lafaz 'قَرْضَاً bermaksud pinjaman suka rela yang diinfakkan oleh seseorang yang berharta kepada orang lain. Berdasarkan ayat di atas, Allah SWT akan melipat gandakan ganjaran kepada sesiapa yang membantu orang lain dengan memberikan sebahagian hartanya kepada orang lain.

\section{c) Membangunkan Etika Kerja Individu ${ }^{60}$}

Islam sangat menganjurkan umatnya agar sentiasa berusaha untuk memperbaiki taraf hidup dirinya. Pembangunan etika kerja sangat membantu manusia dalam meningkatkan inisiatif manusia dalam memperbaiki taraf hidup. Firman Allah SWT di dalam al-Quran:

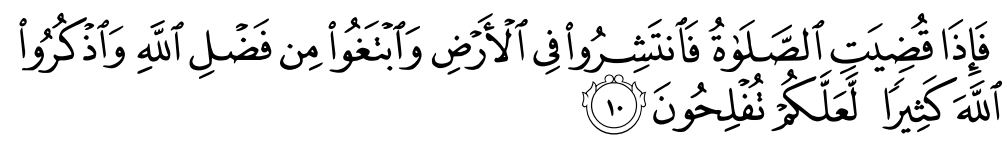

"Apabila telah ditunaikan solat, maka bertebaranlah kamu di muka bumi; dan carilah kurnia Allah dan ingatlah Allah banyakbanyak supaya kamu beruntung."

(Surah al-Jumu'ah, 62: 10)

Melalui etika kerja, nilai-nilai murni dapat diterapkan kepada manusia yang membentuk keperibadian semasa bekerja yang kemudiannya membentuk semangat dan saling berdaya saing antara satu sama lain. Etika kerja dalam Islam menggambarkan keperibadian seseorang yang bekerja dengan menumpukan kemampuan mereka dalam mencipta inovasi dan kreativiti.

\section{ISLAM DAN PEMBASMIAN KEMISKINAN BANDAR}

Islam adalah penyelesaian kepada segala permasalahan manusia. Walau bagaimanapun, sumber-sumber yang ada masih belum digali, dicerna dan diterjemahkan secara maksimum kepada pelbagai bentuk modul dan program ke arah penyelesaian masalah umat dan ke arah pembinaan manusia. Islam memandang kemiskinan sebagai satu fenomena yang mesti diatasi kerana

60_Razaleigh Muhamat @ Kawangit, Pengurusan Etika Kerja dan Perkhidmatan Islam, (Bangi: Universiti Kebangsaan Malaysia, 2014), 21-24. 
umat Islam tidak akan berkembang dan sempurna dalam keadaan masyarakat yang lemah dan pasif. Jurang pendapatan yang besar juga tidak Islamik kerana Islam sangat mementingkan kesama rataan dan keadilan sosial. ${ }^{61}$ Dalam konteks kajian ini, kemiskinan bandar dilihat oleh Islam sebagai sesuatu keadaan yang mesti diatasi kerana kesan buruknya ke atas individu, masyarakat dan keunggulan agama Islam sebagai penyelesaian masalah sosial, ekonomi, politik, budaya dan sahsiah. Setelah meneliti pandangan Islam mengenai kemiskinan, subtopik ini akan mengetengahkan apakah kaedah ataupun stratergi Islam dalam membasmi isu kemiskinan bandar. Strategistrategi ini dibahagikan kepada dua pihak yang perlu memainkan peranan bagi menangani isu kemiskinan bandar, iaitu rakyat dan pemerintah.

\section{Peranan Rakyat}

\section{a) Memperbetulkan Aqidah Berkenaan Ekonomi ${ }^{62}$}

Usaha pembasmian kemiskinan bandar perlu bermula dengan memastikan kefahaman terhadap kesahihan aqidah berkenaan ekonomi pada diri individu fakir miskin dan masyarakat direalisasikan. Usaha Ini merangkumi tiga perkara, iaitu: (i) kefahaman yang benar tentang qada' dan qadar dalam masalah kemiskinan, (ii) kefahaman yang betul tentang keseimbangan antara pengeluaran ekonomi dan keperluan manusia, serta (iii) kefahaman yang betul tentang hak pemilikan harta sebenar adalah Allah SWT.

Seseorang yang memiliki aqidah yang jelas dan menganggap kemiskinan suatu perkara yang boleh diubah akan lebih optimis, berusaha dan bekerja untuk mengatasi kemiskinan, mendorongnya memiliki harta dan tidak mengabaikan aspek material dalam kehidupan sehari-hari. Ini disebabkan sesuatu keadaan tidak akan dapat diubah melainkan diri sendiri yang berubah terlebih dahulu, dan semuanya bertitik tolak daripada keyakinan dan pemikiran seseorang individu.

Selain itu, keyakinan bahawa Allah SWT menjadikan hasil ekonomi mencukupi bagi menampung keperluan manusia sejagat akan menjadikan

61 Mahfooz Ahmed, 'Distributive Justice and Fiscal \& Monetary Economics in Islam', in Readings in Public Finance in Islam, ed. Mahmoud A. Guliad \& Mohamed Aden Abdullah (Jeddah: Islamic Research and Training Institute, 1995), 232.

62 Mohd Fauzi Hamat, 'Peranan Akidah dalam Perancangan Pembangunan Ummah: Satu Analisis dalam Konteks Masyarakat Kini’, Jurnal Usuluddin, no. 16 (2002), 13-34. 
ummat manusia sentiasa positif dalam usaha membasmi kemiskinan. Allah SWT berfirman:

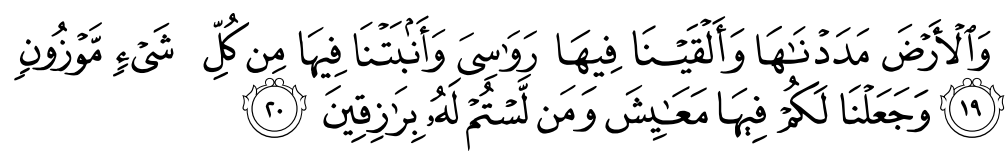

"Dan Kami telah menghamparkan bumi dan menjadikan padanya gunung-ganang dan Kami tumbuhkan padanya segala sesuatu mengikut ukurannya. Dan Kami telah menjadikan untukmu keperluan-keperluan hidup, dan kami menciptakan pula makhluk-makhluk yang bukan kamu pemberi rezeki kepadanya."

(Surah al-Hijr, 15: 19-20)

Kemudian, persoalan bagaimana manusia akan memperolehi bahagian rezeki masing-masing yang ditetapkan oleh Allah SWT adalah bergantung kepada kerja manusia, sistem masyarakat yang digunakan, kaedah pengurusan ekonomi dan sistem politik yang menaungi manusia. Kefahaman terhadap prinsip harta adalah milik Allah SWT pula akan mendatangkan sifat insaf bahawa harta yang dimiliki adalah amanah Allah SWT untuk digunakan pada jalan yang disyariatkan dan manusia tertakluk kepada tanggungjawab kemasyarakatan yang perlu dilunaskan seperti zakat, nafkah, sedekah dan lainlain.

\section{b) Pengagihan Harta daripada Golongan Kaya Kepada Golongan Miskin ${ }^{63}$}

Kaedah ini merupakan kaedah yang terakhir dalam membanteras kemiskinan bandar. Kaedah ini pula terbahagi kepada tiga peringkat, iaitu:

i) Peringkat Wajib: iaitu kewajipan menunaikan nafkah yang wajib ke atas anggota keluarga dan mengeluarkan zakat bagi peringkat masyarakat.

ii) Peringkat Pilihan: galakan Islam agar bersedekah secara sukarela (sunat). Ini adalah peringkat penyempurnaan, bukan satu-satunya cara yang digunakan oleh Islam seperti yang disangka oleh musuh Islam.

63 Nuruul Hidayah Mansor, S. Salahudin Suyurni \& Norajila Che Man, 'Pemerkasaan Agihan Zakat Sebagai Medium Pembangunan Masyarakat Islam', Prosiding, Seminar Antarabangsa Dakwah dan Etnik 2014: Da'wah \& Ethnicity: Multidisciplinary Perspective (Kota Kinabalu: Pusat Penataran Ilmu dan Bahasa Universiti Malaysia Sabah, 2014), 1-14. 
iii) Peringkat Wajib: contohnya melalui kewajipan membayar cukai. Peringkat ini tidak diperlukan jika peringkat sebelumnya telah memadai dan ini merupakan peringkat terakhir dalam usaha memerangi kemiskinan bandar.

Kaedah ini juga membuktikan keistimewaan pendekatan Islam dalam membasmi kemiskinan bandar kerana:

i) Islam mengambil berat terhadap golongan yang tidak diambil berat oleh sistem lain seperti golongan penghutang yang tidak mampu melunaskan hutang mereka dan ibn sabīl (musafir yang kehabisan bekalan perjalanan) melalui pemberian zakat

ii) Wujudnya hukuman berbentuk bantuan kemasyarakatan seperti kaffarah yang mewajibkan pengeluaran harta kepada golongan fakir miskin

iii) Sedekah tidak diwajibkan, sebaliknya bergantung kepada pilihan individu sendiri sebagai peringkat penyempurnaan kepada peringkat sebelumnya (zakat dan nafkah).

\section{c) Sikap dan Motivasi ${ }^{4}$}

Pemilikan harta untuk memperolehi kehidupan yang selesa adalah fitrah manusia yang dijadikan Allah SWT. Firman Allah SWT di dalam al-Quran:

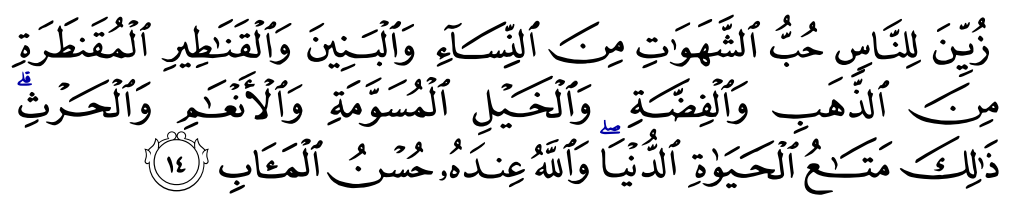

"Dijadikan indah pada (pandangan) manusia kecintaan kepada apa-apa yang diingini, iaitu wanita-wanita, anak-anak, harta yang banyak dari jenis emas, perak, kuda pilihan, binatangbinatang ternak dan sawah ladang. Itulah kesenangan hidup di dunia; dan di sisi Allah tempat kembali yang baik (syurga)."

(Surah Āli ‘Imrān, 3: 14)

Sebenarnya terdapat pelbagai motivasi dalam Islam untuk menggalakkan umatnya mencari harta atau meningkatkan pendapatan. Pemilikan harta menjadi salah satu syarat untuk menunaikan dua rukun Islam iaitu mengeluarkan zakat dan menunaikan haji. Ini sebenarnya adalah insentif untuk umat

64 Hussein Azeemi Abdullah Thaidi, Muhamad Firdaus Ab Rahman \& Azman Ab Rahman, 'Analisis Strategi Pemerkasaan Asnaf Fakir dan Miskin Berdasarkan Hadis Lelaki Ansar,' Journal of Fatwa Management and Research, vol. 17/2 (2019), 454. 
Islam meningkatkan pendapatan atau mencari harta. Harta berlebihan yang disedekah, diwakafkan atau yang ditinggalkan kepada waris atau diwasiatkan semasa meninggal dunia pula boleh menambahkan amal jariah yang sangat dituntut dalam Islam.

Masalah kesedaran tentang pentingnya pencarian harta perlu ditekankan dalam kalangan umat Islam di Malaysia terutama yang berpendapatan rendah. Ini adalah kerana kemiskinan sangat merbahaya terhadap pembentukan masyarakat yang sihat, terutamanya terhadap individu. Ia boleh mendatangkan beberapa implikasi negatif dalam kehidupan manusia, terutamanya dari segi akidah. Kemiskinan boleh menyebabkan seseorang itu terpesong daripada ajaran Islam. Kemiskinan akan mengundang keraguan terhadap peraturan Allah di atas dunia ini serta dapat menimbulkan kepercayaan terhadap adanya ketidakadilan dalam pembahagian rezeki. Ini jelas sebagaimana tergambar dalam hadis dari Anas bin Malik RA, Rasulullah SAW bersabda:

$$
\text { كاد الفقر أن يكون كفر ا }
$$

"Hampir-hampir kemiskinan itu menjadikan seseorang itu kufur." 65

Bahaya kemiskinan ini amat besar sehingga Rasulullah SAW memohon perlindungan Allah SWT daripada ancaman kemelaratan yang disejajarkan dengan permohonan lindungan terhadap kekufuran dalam satu ungkapan sepertimana berikut:

$$
\text { اللّهم إنّي أعوذ بك من الكفر والفقر وعذاب القبر }
$$

"Ya Tuhanku, aku berlindung kepadaMu, dari bahaya kekufuran dan kemelaratan serta azab kubur." 66

Gejala kemiskinan bandar boleh memberi kesan terhadap keamanan dan ketenteraman masyarakat. Mereka terdorong untuk menceburkan diri

65 Al-Bayḥaqī, Abū Bakr Aḥmad Ibn al-Ḥusayn, Shu 'ab al-İmān, vol. 5, "al-Thalith wa al-Arba'ūn min Shu'ab al-Imān, Bāb al-Hithth 'ala Tark al-Ghill wa al-Hasad," no. hadis 6612 (Bayrut: Dār al-Kutub al-'Ilmiyyah, 1996), 267; Abū Nu'aym Aḥmad Ibn 'Abd Allāh al-Asfihānī, Hilyah al-Awliyā' wa Ṭabaqāt al-Asfiya, vol. 3, Yazid Ibn Aban al-Ruqasyi (205), (Bayrūt: Dār al-Kutub al-'Ilmiyyah, t.t.), 53; Al-'Ajlunī menyatakan bahawa hadis ini adalah da îf kerana terdapat perawi yang bernama al-Ruqasyi di dalamnya. Lihat Ismā'̄̄l Ibn Muḥammad al-'Ajlunī, Kashf al-Khufa wa Muzil al-Ilbās 'Amma Ishtahara min al-Ahāadith 'ala al-Sinah al-Nās, vol. 2 (Bayrūt: Dār Ihyyā’ al-Turāth al-'Arabī, t.t.), 107-108.

66 Yūsuf al-Qaraḍāwī, Mushkilah al-Faqr wa Kayfa 'Alajaha al-Islām (Bayrūt: Mu'assasah al-Risālah, 1997), 13-18. 
dalam kegiatan yang boleh menyusahkan dan mengganggu orang lain akibat daripada desakan untuk memenuhi keperluan jasmani seperti mencuri dan pelbagai jenayah lain. Kekacauan juga boleh terjadi akibat ketidakadilan dalam pembahagian pendapatan dalam kalangan masyarakat.

\section{Peranan Pemerintah}

\section{a) Pengkhususan dan Keutamaan dalam Pengagihan Hasil Ekonomi ${ }^{67}$}

Islam memiliki pengkhususan ekonomi yang tersendiri yang merangkumi tiga jenis pengkhususan, iaitu; a) Pengkhususan antara sektor awam dan sektor swasta, b) Pengkhususan antara generasi kini dan generasi akan datang, dan c) Pengkhususan dalam sektor awam. Dalam sektor awam misalnya, Saidina 'Umar al-Khaț̣āb pernah mengkhususkan suatu kawasan yang bernama 'al-Sharaf' untuk golongan miskin yang menggembala ternakan dan beliau berpesan kepada petugas yang menjaga kawasan tersebut agar tidak mengizinkan kawasan tersebut dimasuki oleh ternakan golongan kaya. Selain itu, kerajaan boleh menggunakan sektor awam dalam bidang pertanian untuk melaksanakan projek ekonomi yang memberi peluang pekerjaan kepada golongan miskin.

Contoh pengkhususan untuk generasi akan datang pula terjadi ketika mana Khalifah 'Umar al-Khațāa bertindak tidak membahagikan 'arḍ al-sawad' yang merupakan ghanimah hasil penaklukan Iraq, Khurasan, Mesir dan lainlain kepada tentera Islam sebaliknya mengkhususkan tanah tersebut untuk kegunaan generasi akan datang. Hikmahnya adalah untuk mengatasi masalah kemiskinan warisan. Dengan erti kata lain pihak kerajaan bertanggungjawab mengagihkan ekonomi mengikut pengkhususan yang adil dan tepat agar masalah kemiskinan bandar dapat diatasi dan hasil ekonomi tidak dikaut sebesarnya olah golongan tertentu sahaja sekali gus menjamin keseimbangan setiap lapisan masyarakat.

\section{b) Pengurusan Ekonomi Terancang dan Berstrategi}

Pemimpin, pembuat dasar, pihak berwajib dan pihak-pihak lain perlu membuat perancangan yang jelas dan berstrategi dalam mengemukakan model pengurusan ekonomi yang mesra kepada golongan miskin bandar. Ini

${ }_{67}$ Hussin Abdullah \& Ferayuliani Yuliyusman, 'Kesan Kebebasan Ekonomi terhadap Pertumbuhan Ekonomi Negara: Kajian Empirikal di ASEAN-5,' Journal of Governance and Development, vol. 6/1 (2010), 5. 
adalah berdasarkan kepada beberapa kaedah syara', antaranya: ${ }^{68}$ a) Tindakan pemimpin ke atas rakyatnya berdasarkan kepada maṣlaḥah (عرف الامام (على الرعية منوط بالمصلحة. Kaedah ini menyarankan kepada para pemimpin agar mengambil kira kemaslahatan rakyat dalam menentukan sesuatu dasar terutamanya pembasmian kemiskinan, b) Mengambil mudarat yang khusus bagi mengelakkan mudarat yang umum (يتحمل الضرر الخاص لدفع الضرر العام). Kaedah ini bererti mengutamakan mașlahah yang lebih umum daripada mașlaḥah yang khusus apabila bertembung dua mașlaḥah, c) Mudarat yang lebih berat dihilangkan dengan mudarat yang lebih ringan (الضرر الأشد يزال) (بالضرر الأخف . Kaedah ini digunakan apabila bertembung dua kemudaratan, satu lebih ringan daripada yang lain. Sebagai contoh, menentukan dasar ekonomi yang tidak memudaratkan golongan miskin yang ramai sekalipun memudaratkan sebahagian golongan kaya.

\section{c) Mengamalkan Ekonomi Berkeutamaan}

Kaedah ini digunakan oleh kerajaan dalam pengkhususan aktiviti ekonomi dan pengagihan hasil ekonomi agar selari dengan kehendak syara'. Ini dapat dilaksanakan mengikut keutamaan berdasarkan objektif Syarak, iaitu: ${ }^{69}$

i) Maqāṣid al-Ḍarūriyyāt; mendirikan mașlaḥah duniawi yang jika diabaikan akan membawa kematian dan kemusnahan hidup dan maṣlahah ukhrawi yang jika diabaikan membawa penyesalan di hari kiamat. Ini terangkum dalam lima aspek al-darūriyyāt, iaitu menjaga agama, jiwa, keturunan, harta dan aqal. Contohnya seperti makanan, minuman, pakaian, tempat tinggal, bekalan air, keamanan, pertahanan dan pendidikan.

ii) Maqāșid al-Hājiyyāt; perkara yang yang diperlukan oleh menusia untuk mengelakkan kepayahan dan kesempitan. Contohnya: perhubungan dan pengangkutan awam dengan kos yang berpatutan dan tidak membebankan golongan miskin bandar dan menjadikan golongan pertengahan jatuh ke dalam kelompok miskin bandar.

iii) Maqāṣid al-Tahsiniyyāt; perkara yang mengindahkan kehidupan dan mengelakkan perkara yang ingin dijauhi oleh akal yang waras. Ini termasuk segala bentuk keperluan yang harus dan tidak ditegah oleh syara'.

68 Mohammad Hashim Kamali, 'Qawa'id Al-Fiqh: The Legal Maxims of Islamic Law' (artikel, The Association of Muslim Lawyers, UK, t.t.), 2-7.

69 Rafidah Mohd Azli et al., 'Aplikasi Maqasid Shariah dalam Kewangan Islam', (Kertas kerja, Seminar Hukum Islam Semasa, Jabatan Fiqh \& Usul, Akademi Pengajian Islam Universiti Malaya, 14-15 Disember 2011), 4-7. 
Pengurusan ekonomi berdasarkan keutamaan sangat penting bagi memastikan sumber ekonomi mencukupi bagi menampung keperluan manusia. Keutamaan ini boleh berubah berdasarkan suasana dan keadaan masyarakat. Seringkali terjadi, hasil ekonomi tidak mencukupi akibat mengutamakan perkara hâjiyyāt dan tahsiniyyāt berbanding al-darūriyyāt atau seumpamanya hingga menyebabkan masalah kemiskinan menjadi bertambah buruk walaupun negara mempunyai sumber bumi yang melimpah-ruah. Contohnya, berlumbalumba membina bangunan yang mewah, sedangkan masih ramai rakyat yang terbiar tiada tempat kediaman dan tidak cukup makanan.

\section{d) Perumusan Dasar Pembasmian Kemiskinan yang Lebih Berkesan ${ }^{70}$}

Berasaskan kepada cabaran yang dihadapi oleh masyarakat Islam pada masa kini, usaha pembasmian kemiskinan perlu dibezakan kepada dua jangka masa iaitu jangka pendek dan jangka panjang. Kegiatan jangka pendek perlu berusaha meningkatkan pendapatan keluarga-keluarga miskin, sama ada dalam bentuk bantuan (pemberian), pinjaman, peningkatan kemahiran, perbaikan pemasaran dan menyediakan peluang untuk menjalankan kegiatan di sektor perkhidmatan (misalnya berniaga). Manakala program jangka panjang adalah usaha untuk meningkatkan pendidikan anak-anak golongan miskin sehingga mereka dapat keluar dari keadaan kemiskinan pada ketika mereka dewasa. Seterusnya, dalam menentukan bentuk bantuan yang akan diberikan, perlulah dibuat penggolongan ke atas keluarga-keluarga miskin yang akan dibantu. Perlulah disedari bahawa golongan miskin bukanlah masyarakat yang homoginis. Oleh itu, dalam merancang dan merumuskan program pembasmian kemiskinan perlu dibuat penggolongan berasaskan kepada bentuk usaha pembasmian kemiskinan yang akan dijalankan. Berikut dikemukakan bentuk penggolongan yang boleh digunakan;

Jadual 2: Penggolongan Penduduk Bandar/Sekitar Bandar Miskin

\begin{tabular}{ccc}
\hline Bil. & Penggolongan Penduduk & Keterangan \\
\hline 1. & Golongan Uzur dan Cacat & Tiada anak \\
& & Sedikit anak \\
& & Ramai anak \\
\hline
\end{tabular}

70 Siwar Chamhuri \& Khairi Ismail, 'Cabaran Pensasaran Kemiskinan: Pengajaran Daripada Program Pembangunan Rakyat Termiskin (PPRT) dan Implikasi Terhadap Golongan B40', dalam Pemerkasaan B40: Kesejahteraan Strategi dan Implikasi Sosioekonomi (Bangi: Penerbit Universiti Kebangsaan Malaysia, 2019), 310. 
Bil. Penggolongan Penduduk

2. Golongan Kurang Keazaman Untuk Bekerja

3. Golongan Cukup Keazaman Untuk Bekerja dan Berusaha
Keterangan

Tiada anak

Sedikit anak

Ramai anak

Tiada anak

Sedikit anak

Ramai anak

Dengan menggunakan penggolongan di atas, seterusnya perlulah dikenal pasti program jangka pendek yang akan dijalankan untuk membantu setiap golongan tersebut. Program jangka panjang perlu menitikberatkan kepada meningkatkan taraf pendidikan anak-anak dari setiap golongan tersebut. Bantuan yang diberikan tidak semestinya dihadkan kepada pencapaian akademik sahaja, bahkan kepada magnitud dari masalah kemiskinan yang mereka hadapi.

\section{e) Strategi Pertumbuhan}

Islam sangat menggalakkan manusia menggunakan segala kurniaan Allah SWT untuk kebaikan. Pertumbuhan ekonomi akan menghalang pembekuan harta kerana pembekuan atau pengumpulan harta dalam jumlah yang besar boleh membawa kepada nilai yang tidak baik seperti angkuh, sombong, penindasan dan pengeksploitasian terhadap golongan yang miskin. ${ }^{71}$ Ia juga akan membuka peluang pekerjaan dan perniagaan kepada masyarakat. Namun begitu, pertumbuhan tersebut hendaklah dinikmati sama rata oleh rakyat walaupun Islam mengenal pasti perbezaan dari segi kemahiran dan kapasiti antara satu sama lain. Perbezaan pendapatan hasil daripada perbezaan anugerah Allah SWT boleh diatasi dengan had yang dikenakan oleh Islam seperti mengagihkan pendapatan yang berlebihan setelah cukup keperluan kepada orang yang kurang berkemampuan.

\section{i) Guna Tenaga}

Seseorang yang mencari rezeki dengan bekerja untuk memenuhi keperluan diri sendiri dan keluarga adalah suatu bentuk ibadah. Dalam al-Quran ada dinyatakan;

71 Naseem, Quazi, 'Economic Morality in Islam', Hamdard Islamicus, vol. 16/4 (1993): 23. 


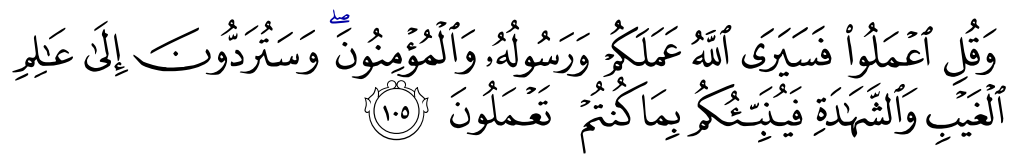

"Dan katakanlah: Bekerjalah kamu, maka Allah dan Rasul-Nya serta orang-orang mukmin akan melihat pekerjaanmu itu, dan kamu akan dikembalikan kepada (Allah) Yang Mengetahui yang ghaib dan yang nyata lalu diberitakan-Nya kepada kamu apa yang telah kamu kerjakan."

(Surah al-Tawbah, 9: 105)

Dengan bekerja, seseorang boleh mengelakkan diri dan keluarganya daripada sifat meminta-minta, malah boleh menyumbang kepada orang yang memerlukan. Berkaitan dengan hal ini, terdapat hadis Rasulullah SAW, dari Hakim bin Hiram RA dari Nabi SAW bersabda:

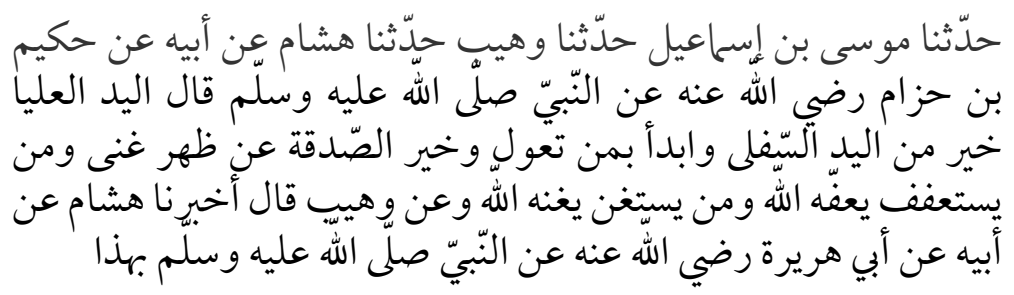

"Telah menceritakan kepada kami (Musa bin Isma il) telah menceritakan kepada kami (Wuhayb) telah menceritakan kepada kami (Hisyam) dari ayahnya dari (Hakim bin Hiram RA dari Nabi SAW bersabda: "Tangan yang di atas lebih baik daripada tangan yang dibawah, maka mulailah untuk orang-orang yang menjadi tanggunganmu dan sedekah yang paling baik adalah dari orang yang sudah cukup (untuk keperluan dirinya). Maka barangsiapa yang berusaha memelihara dirinya, Allah akan memeliharanya dan barangsiapa yang berusaha mencukupkan dirinya, maka Allah akan mencukupkannya." 72

72 Hadis riwayat al-Bukhārī, "Kitāb al-Zakāh, Bāb La Șadaqah Illa 'an Ẓāhir Ghannī”, no. hadis 1427. Lihat al-Bukhārī, Abī 'Abd Allāh Muḥammad Ibn Ismā'īl al-Ju'fì, Ṣah̄ị al-Bukhārī, 347; Hadis riwayat Muslim. Kitāb al-Zakāh, Bāb Bayānun 'An al-Yad al-'Ulya Khayr Min al-Yad al-Suflā, wa 'an al-Yad al-'Ulyā Hiya alMunfaqah wa 'an al-Suflā Hiya al-Akhzah, no. hadis 1034. Lihat Muslim, Ab̄̄ al-Ḥusayn Muslim Ibn al-Ḥajjāj Ibn al-Qushayrī al-Naysabūrī, Șaḥịh Muslim, 717. 


\section{ii) Peluang-peluang Perniagaan}

Kemiskinan akan menghalang usaha pembangunan negara kerana golongan miskin tidak dapat melibatkan diri dalam lapangan pembangunan ekonomi negara seperti pelaburan, perindustrian dan lain-lain. Dengan itu, mereka tidak dapat menyumbangkan khidmat baktinya kepada masyarakat dan negara seperti mengeluarkan zakat dan sedekah. Manakala kesan pelaburan dari sumber zakat juga boleh mewujudkan industri dengan pembukaan kilang baru, mampu menyediakan peluang pekerjaan dan seterusnya dapat meningkatkan kadar guna tenaga dan pendapatan masyarakat. Namun begitu, seseorang akan mendapat apa yang diusahakan sahaja seperti yang telah dinyatakan dalam al-Quran:

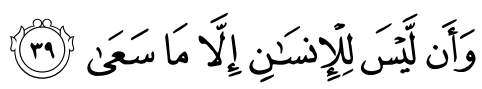

"Dan bahawasanya seseorang manusia tiada memperoleh selain apa yang telah diusahakannya."

(Surah al-Najm, 53: 39)

Meskipun hak memiliki harta diterima oleh Islam, harta-harta yang dimiliki tetapi tidak diusahakan atau jika tidak boleh menggunakannya dengan produktif, maka hendaklah diberi kepada orang lain yang boleh menggunakannya dengan lebih baik. ${ }^{73}$

\section{f) Kemudahan Asas}

Infrastruktur pembangunan ini mengandungi dua bentuk, iaitu luaran dan dalaman. Infrastruktur dalaman lebih menumpukan kepada aspek fizikal seperti kemudahan tempat tinggal, serta bekalan elektrik dan air. Sementara infrastruktur luaran pula lebih merujuk kepada penerimaan disiplin ilmu dan pengetahuan serta teknologi moden sebagai alat kepada pembangunan seperti keupayaan mendapatkan perkhidmatan kesihatan, pendidikan, pengangkutan, komunikasi dan keselamatan. ${ }^{74}$ Gabungan kedua-dua infrastruktur itu akan dapat menyediakan kemudahan yang perlu bagi meneruskan pembangunan masyarakat bandar. Infrastruktur yang disediakan akan membolehkan usaha pembangunan berikutnya bergerak dalam suatu struktur disiplin yang teratur dan lebih berkesan.

73 Mahfooz Ahmed, 'Distributive Justice and Fiscal and Monetary Economics in Islam', 234.

74 Hailani Muji Tahir, Baitulmal: Institusi Kewangan Negara Islam (Kajang: ArRahmaniah, 1982), 31. 


\section{g) Peranan Institusi ${ }^{75}$}

Terdapat beberapa institusi di Malaysia yang terlibat secara langsung dan tidak langsung dalam usaha membasmi kemiskinan. Antaranya adalah Baitulmal, Yayasan Pembangunan Ekonomi Islam Malaysia (YPEIM), Institusi Perbankan Islam dan Badan-badan bukan kerajaan. Di Malaysia, hak penentuan hukum yang berkaitan dengan harta seperti wakaf, zakat, fitrah dan Baitulmal disenaraikan di bawah kerajaan negeri.

\section{KESIMPULAN}

Dalam usaha membasmi kemiskinan bandar di era global, inisiatif yang bersifat lebih kreatif, inovatif dan eksploratif wajar dilaksanakan bagi membuka peluang dan meningkatkan penglibatan rakyat dalam aktiviti ekonomi. ${ }^{76} \mathrm{Hal}$ ini dapat dilaksanakan dengan mengembangkan penggunaan sumber tenaga manusia dan sumber alam, di samping melaksanakan aktiviti ekonomi berpandukan kepada peraturan yang telah ditetapkan dalam al-Quran dan as-Sunnah. ${ }^{77}$ Malaysia sebagai sebuah negara Islam sendiri menganjurkan umatnya agar sentiasa rajin bekerja, dalam mencari kesejahteraan hidup. Apa yang penting adalah penglibatan dan komitmen semua pihak untuk memberi tumpuan pada permasalahan kemiskinan bandar perlu dititikberatkan dalam mencapai kualiti hidup yang lebih baik. Dasar-dasar dan perancangan pembangunan perlu dirangka dengan lebih mesra rakyat agar pembangunan bandar seiring dengan pembangunan ekonomi sara diri rakyat.

\section{RUJUKAN}

'Abd Allāh bin Aḥmad bin Qudāmah, al-Kāfí fì al-Fiqh Hanbāl (t.t.p.: alMaktabah al-Islāmī, 1988).

Abdul Rahman Talib \& Hasan Ahmad, 'Penilaian Kelayakan Asnaf Fakir dan Miskin Berdasarkan Had Kifayah,' International Journal of Humanities Technology and Civilization, no. 5 (2019), 298-306.

\footnotetext{
75 Azman Ab Rahman, Hussein Azeemi Abdullah Thaidi \& Muhamad Firdaus Ab Rahman, 'Peranan Institusi Zakat dan Model Pengurusan Kebajikan Warga Emas Berasaskan Maqasid Syariah: Tinjauan Awal di Selangor,' Prosiding, Persidangan Industri Warga Emas Kebangsaan 2019: Menuju Pengurusan Patuh Syariah (Nilai: Universiti Sains Islam Malaysia, 2019), 10-13.

76 Nur Kholis, 'Pendidikan Islam dalam Usaha Mengatasi Kemiskinan', Jurnal Kependidikan, vol. 2/2 (2014): 13.

77 Hamdani, 'Kemiskinan dalam Pandangan Ekonomi Syariah,' Jurnal Studi Islam dan Sosial, vol. 9/2 (2015), 10.
} 
Abū Nu'aym Aḥmad Ibn 'Abd Allāh al-Asfihānī, Hilyah al-Awliyā'wa Ṭabaqāt al-Asfiya, vol. 3 (Bayrūt: Dār al-Kutub al-'Ilmiyyah, t.t.).

Alexandra M. Curley, 'Theories of Urban Poverty and Implications for Public Housing Policy,' Journal of Sociology and Social Welfare, vol. 32/2 (2005): 97-119.

Azman Ab Rahman, Hussein Azeemi Abdullah Thaidi \& Muhamad Firdaus Ab Rahman, 'Peranan Institusi Zakat dan Model Pengurusan Kebajikan Warga Emas Berasaskan Maqasid Syariah: Tinjauan Awal di Selangor,' Prosiding, Persidangan Industri Warga Emas Kebangsaan 2019: Menuju Pengurusan Patuh Syariah (Nilai: Universiti Sains Islam Malaysia, 2019).

Al-Bayḥaq̄ī, Abū Bakr Aḥmad Ibn al-Ḥusayn, Shu 'ab al-Īmān, vol. 5 (Bayrut: Dār al-Kutub al-'Ilmiyyah, 1996).

Al-Bukhārī, Abī ‘Abd Allāh Muḥammad Ibn Ismā'īl al-Ju'fì, Ṣaḥịh al-Bukhārī (Bayrūt: Dār Ibn Kathīr, 2002).

Caroline O.N. Moser, 'The Asset Vulnerability Framework: Reassessing Urban Poverty Reduction Strategies,' World Development, vol. 26/1 (1998), 1-19.

Chriswardani Suryawati, 'Memahami Kemiskinan Secara Multidimensional,' Jurnal Manajemen Pelayanan Kesehatan, vol. 8/3 (2005), 121-129.

David Satterthwaite, 'Reducing Urban Poverty: Constraints on the Effectiveness of Aid Agencies and Development Banks and Some Suggestions for Change,' Environment and Urbanization, vol. 13/1 (2001), 137-158.

Denison Jayasooria, Inclusive Development for Urban Poor and Bottom 40\% Communities in Malaysia (Bangi: Institut Kajian Etnik Universiti Kebangsaan Malaysia, 2016).

Diana Mitlin, 'Addressing Urban Poverty through Strengthening Assets,' Habitat International, vol. 27/3 (2003): 393-406.

Economic Planning Unit, The Malaysian Economy in Figure 2016 (Putrajaya: Economic Planning Unit, 2016).

Gerald Rosenthal, 'Identifying the Poor: Economic Measures of Poverty,' in On Understanding Poverty, ed. Danial P. Moynihan Moynihan (New York: Basic Book Inc. Publisher, 1969), 330-342.

Al-Ghazzālī, Abū Hamīd Muḥammad Ibn Aḥmad, Ihyyà' 'Ulūm al-Dìn, vol. 7 (Indonesia: Penerbit Asli, 1988).

Hailani Muji Tahir, Baitulmal: Institusi Kewangan Negara Islam (Kajang: ArRahmaniah, 1982). 
Hamdani, 'Kemiskinan dalam Pandangan Ekonomi Syariah,' Jurnal Studi Islam dan Sosial, vol. 9/2 (2015), 1-9.

Al-Hisān̄̄, Taqī al-Dīn, Ab̄̄ Bakr bin Muḥammad al-Husayn̄̄, Kifāyah alAkhyār fì Halli Ghāyah al-Ikhtișār (Bayrūt: Dār al-Kutub al-'Ilmiyyah, 2001).

Hussein Azeemi Abdullah Thaidi, Muhamad Firdaus Ab Rahman \& Azman Ab Rahman, 'Analisis Strategi Pemerkasaan Asnaf Fakir dan Miskin Berdasarkan Hadis Lelaki Ansar,' Journal of Fatwa Management and Research, vol. 17/2 (2019), 446-457.

Hussin Abdullah \& Ferayuliani Yuliyusman, 'Kesan Kebebasan Ekonomi terhadap Pertumbuhan Ekonomi Negara: Kajian Empirikal di ASEAN-5, Journal of Governance and Development, vol. 6/1 (2010), 410-423.

Ismā'1̄l Ibn Muhammad al-'Ajlun̄̄, Kashf al-Khufa wa Muzil al-Ilbās 'Amma Ishtahara min al-Ahāadith 'ala al-Sinah al-Nās, vol. 2 (Bayrūt: Dār Ihyyā' al-Turāth al-'Arabī, t.t.).

Itang, 'Faktor-Faktor Penyebab Kemiskinan', Jurnal Keislaman, Kemasyarakatan dan Kebudayaan, vol. 16/1 (2015): 1-25.

Hassan N. Khalid, 'Satu Analisis Mengenai Dikotomi Antara kemiskinan Bandar dan Luar Bandar di Malaysia,' Perspektif: Jurnal Sains Sosial dan Kemanusiaan, vol. 4/1 (2012): 1-21.

Jabatan Perangkaan Malaysia, Laporan Penyiasatan Pendapatan Isi Rumah dan Kemudahan Asas Mengikut Negeri dan Daerah Pentadbiran (Kuala Lumpur: Jabatan Perangkaan Malaysia, 2017).

Judy L. Baker, 'Urban Poverty: A Global View (English), ' Urban Paper, no. UP-5 (Washington, DC: World Bank, 2008), 1-27.

Kamal Salih, 'Konsep, Definisi dan Pengukuran Kemiskinan', dalam Kemiskinan Luar Bandar, ed. Aladin H., Alang Perang \& A.W. Hashim (Kuala Lumpur: Penerbit AIM, 1984), 39-51.

Katiman Rostam, 'Kecekapan Ekonomi Ruang Bandar Versus Ketaksamaan Pembangunan di Malaysia: Suatu Pola Pembandaran dalam Era Perubahan Global', dalam Isu-Isu Semasa Alam Sekitar Manusia di Malaysia, ed. Yazid Saleh, Fauziah Che Leh \& Mazdi Marzuki (Tanjong Malim: Penerbit Universiti Pendidikan Sultan Idris, 2010), 1-19.

Katiman Rostam, Pengantar Geografi Bandar (Kuala Lumpur: Dewan Bahasa dan Pustaka, 1988).

Katiman Rostam, Prinsip Asas Persekitaran Manusia (Bangi: Universiti Kebangsaan Malaysia, 2002). 
Kurshid Ahmad, 'Economic Development in An Islamic Framework', dalam Studies in Islamic Economics, ed. Kurshid Ahmad (Leicester: Islamic Foundation, 1980), 43-61.

Lee Kok Chai \& Wan Rozali, 'Kualiti Hidup Sosial dan Isu-Isu Perumahan: Kajian Kes di Pulau Pinang', dalam Isu-Isu Semasa Alam Sekitar Manusia di Malaysia, ed. Yazid Saleh, Fauziah Che Leh \& Mazdi Marzuki, (Tanjong Malim: Penerbit Universiti Pendidikan Sultan Idris, 2010), 1-23.

Mahfooz Ahmed, 'Distributive Justice and Fiscal \& Monetary Economics in Islam', in Readings in Public Finance in Islam, ed. Mahmoud A. Guliad \& Mohamed Aden Abdullah (Jeddah: Islamic Research and Training Institute, 1995), 311-340.

Martin Ravallion, 'Poverty Lines in Theory and Practice', Living Standards Measurement Study Working Paper, no. 33 (1998), 1-35.

Michael B. Teitz \& Karren Chapple, 'The Causes of Inner-City Poverty: Eight Hypotheses in Search of Reality', Cityscape: A Journal of Policy Development and Research, vol. 3/3 (1998): 33-70.

Mohammad Hashim Kamali, 'Qawa'id Al-Fiqh: The Legal Maxims of Islamic Law' (artikel, The Association of Muslim Lawyers, UK, t.t.).

Mohd Fadzil Abdul Rashid \& Ishak Ab Ghani, 'Migrasi dan Kemiskinan Bandar: Suatu Kajian Literatur', (Kertas kerja, Seminar Kebangsaan Pembangunan Persekitaran \& Masyarakat 2007, Pulau Pinang, 17-18 Januari 2007).

Mohd Fauzi Hamat, 'Peranan Akidah dalam Perancangan Pembangunan Ummah: Satu Analisis dalam Konteks Masyarakat Kini', Jurnal Usuluddin, no. 16 (2002), 13-34.

Muḥammad bin Aḥmad bin Jaz̄̄ al-Kalbī al-Gharnatī, al-Qawānīn al-Fiqhiyyah li Ibn Jazī (Bayrūt: Dār al-Kutub, 1998).

Muhammad Rawwās Qal'ajī, Mawsū'ah Fiqh 'Umar bin al-Khațtāb (Bayrūt: Dār al-Nafash, 1989).

Muhyy al-Dīn 'Abd al-Hamīd, Sabīl al-Fallāh fì Nūr al-Lidah (Bayrūt: Dār alBayrūtī, t.t.).

Muslim, Ab̄̄ al-Husayn Muslim Ibn al-Hajjāj Ibn al-Qushayrī al-Naysabūrī, Șaḥ̄h Muslim bi Sharh al-Imām Muḥy al-Dīn al-Nawaw̄ (Bayrūt: Dār al-Kutub 'Ilmiyyah, 1991).

Naseem, Quazi, ‘Economic Morality in Islam', Hamdard Islamicus, vol. 16/4 (1993): 32-41. 
Nasikun, 'Penanggulangan Kemiskinan: Kebijakan dalam Perspektif Gerakan Sosial', Jurnal Ilmu Sosial dan Ilmu Politik, vol. 6/1 (2002): 1-16.

Nina Herlina \& Mamay Komariah, 'Peran Pemerintah dalam Pengentasan kemiskinan Kabupaten Ciamis', Jurnal Ilmiah Galuh Justisi, vol. 5/2 (2017): 260-277.

Nor Ghani Md. Nor, 'Dimensi Kemiskinan dan Rancangan Pembasmian Kemiskinan', dalam Siri Kumpulan Esei: Ekonomi Pembangunan, ed. Amir Hussin Baharuddin (Kuala Lumpur: Dewan Bahasa dan Pustaka, 1984), 56-72.

Norzita Jamil \& Siti Hadijah Che Mat, 'Realiti Kemiskinan: Satu Kajian Teoritikal', Jurnal Ekonomi Malaysia, vol. 48/1 (2014): 167-177.

Nur Kholis, 'Pendidikan Islam dalam Usaha Mengatasi Kemiskinan', Jurnal Kependidikan, vol. 2/2 (2014): 1-14.

Nuruul Hidayah Mansor, S. Salahudin Suyurni \& Norajila Che Man, 'Pemerkasaan Agihan Zakat Sebagai Medium Pembangunan Masyarakat Islam', Prosiding, Seminar Antarabangsa Dakwah dan Etnik 2014: Da'wah \& Ethnicity: Multidisciplinary Perspective (Kota Kinabalu: Pusat Penataran Ilmu dan Bahasa Universiti Malaysia Sabah, 2014), $1-14$.

Om Prakash Mathur, Urban Poverty in Asian (Philippines: Asian Development Bank, 2014).

Rachel Pain et. al., Introducing Social Geographies (London: Routledge, 2001).

Rafidah Mohd Azli et al., 'Aplikasi Maqasid Shariah dalam Kewangan Islam', (Kertas kerja, Seminar Hukum Islam Semasa, Jabatan Fiqh \& Usul, Akademi Pengajian Islam Universiti Malaya, 14-15 Disember 2011), $1-10$.

Rawlins Wayne E. \& Dzurizah Ibrahim, 'Squatters at the Gateway of Urban Malaysia', in Sustainable Urban Development Issues in Malaysia, ed. Nurhaslina H. (Kuala Lumpur: Dewan Bahasa \& Pustaka, 2009), 34-46.

Razaleigh Muhamat@Kawangit,Pengurusan Etika Kerja dan Perkhidmatan Islam (Bangi: Universiti Kebangsaan Malaysia, 2014).

Sayed Afzal Peerzade, 'The Definition and Measurement of Poverty: An Integrated Islamic Approach', The Pakistan Development Review, vol. 36/1 (1997): 87-97. 
Selamah Abdullah Yusof, Rohaiza Abd Rokis \& Wan Jamaliah Wan Jusoh, 'Financial Fragility of Urban Households in Malaysia', Jurnal Ekonomi Malaysia, vol. 49/1 (2015): 15-24.

Al-Shāfi'ì, Abū 'Abd Allāh Muḥammad Ibn Idrīs, al-Umm (Riyāḍ: Bayt alAfkār al-Dawliyyah, t.t.).

Shaharudin Ahmad, Mikroiklim Bandar: Perkembangan dan Impak Pulau Haba Bandar di Malaysia (Bangi: Universiti Kebangsaan Malaysia, 2012).

Al-Shayban̄̄, Ab̄̄ 'Abd Allāh Muḥammad bin al-Ḥasan, al-Jamī' al-Ṣaghīr (Pakistan: Idārah al-Qur’ān wa al-'Ulūm al-Islāmiyyah, 1990).

Al-Shirāzī, Abū Isḥāq Ibrāhīm Ibn 'Alī Ibn Yūsuf al-Fayrūz Abād̄̄, alMuhadhdhāb fì al-Fiqh al-Imām al-Shāfi ‘’ (Bayrūt: Dār al-Kutub al'Ilmiyyah, t.t.).

Siwar Chamhuri \& Khairi Ismail, 'Cabaran Pensasaran Kemiskinan: Pengajaran Daripada Program Pembangunan Rakyat Termiskin (PPRT) dan Implikasi Terhadap Golongan B40', dalam Pemerkasaan B40: Kesejahteraan Strategi dan Implikasi Sosioekonomi (Bangi: Penerbit Universiti Kebangsaan Malaysia, 2019), 294-303.

Siwar Chamhuri et al., 'Urbanization and Urban Poverty in Malaysia: Consequences and Vulnerability', Journal of Applied Sciences, vol. 16/4 (2016): 154-160.

T.Y. Mok, C. Gan \& A. Sanyal, 'The Determinants of Urban Household Poverty in Malaysia', Journal of Social Sciences, vol. 3/4 (2007): 190-196.

UN ESCAP, 'Urban Poverty Alleviation', in Regional High-level Meeting in Preparation for Istanbul for Asia and the Pacific (Hangzhou: United Nations Centre for Human Settlements, 2000), 54-76.

Unit Perancang Ekonomi, Rancangan Malaysia Kesepuluh (Putrajaya: Unit Perancang Ekonomi Jabatan Perdana Menteri 2010).

Wahbah al-Zuhaylī, al-Fiqh al-Islāmī wa Adillatuh (Dimashq: Dār al-Fikr, 1985).

Wan Nor Azriyati Wan Abd Aziz et al., 'Pembasmian Kemiskinan Bandar ke Arah Bandar Inklusif Sejahtera: Cabaran Kuala Lumpur', Journal of Surveying, Construction and Property, vol. 2/1 (2011): 1-23.

Wan Rozali Wan Hussin, 'Kualiti Hidup Sosial dan Proses Perbandaran di Malaysia', dalam Isu-Isu Semasa Alam Sekitar Manusia di Malaysia, ed. Yazid Saleh, Fauziah Che Leh dan Mazdi Marzuki (Tanjong Malim: Penerbit Universiti Pendidikan Sultan Idris, 2010), 19-42. 
Jurnal Syariah, Jil. 28, Bil. 3 (2020) 461-500

Ya Ping Wang, Urban Poverty Housing and Social Change in China (New York: Routledge, 2004).

Yūsuf al-Qaraḍ̄āī, Mushkilah al-Faqr wa Kayfa 'Alajaha al-Islām (Bayrūt: Mu'assasah al-Risālah, 1997).

Zhou Xuejun, 'Voice of the Urban Poor' (Report on Participatory Urban Poverty Analysis in Beijing, Center for Integrated Agricultural Development (CIAD), 2000). 